\title{
A new species of Bent-toed gecko (Squamata: Gekkonidae: Cyrtodactylus Gray, 1827) from the Garo Hills, Meghalaya State, north-east India, and discussion of morphological variation for C. urbanus
}

\author{
Rachunliu G. Kamei ${ }^{1}$ \& Stephen Mahony ${ }^{2,3}$ \\ 1566 Kohima-Meriema Road (AH1), Meriema, Kohima 797001, Nagaland, India \\ ${ }^{2}$ School of Biology and Environmental Science, University College Dublin, Belfield, Dublin 4, Ireland \\ ${ }^{3}$ Department of Life Sciences, The Natural History Museum, London, SW7 5BD, UK
}

\begin{abstract}
Recent taxonomic and systematic research on Cyrtodactylus khasiensis has found that this nomen comprises a large number of superficially similar but deeply divergent species-level taxa from throughout north-east India and surrounding countries. In this study we focus on the taxonomic status of recently surveyed populations from the East Garo Hills and West Garo Hills districts and a single specimen collected from Ri Bhoi District in Meghalaya State, north-east India. Based on a combination of morphological and molecular data we found that the Ri Bhoi specimen is conspecific with the recently described C. urbanus, and that the Garo Hills populations represent a new species of Cyrtodactylus described herein. Molecular analyses (using the NADH dehydrogenase $2, n d 2$ and adjoining tRNA genes) demonstrate that the new species is nested within the khasiensis group of the Indo-Burma radiation of Cyrtodactylus, and is well-supported as sister to a clade that comprises $C$. septentrionalis and $C$. guwahatiensis. We morphologically compare the new $C$. urbanus specimen with the original description of the species, identify a number of errors and ambiguities in the original description, and notably expand the known morphological variation for the species based on 23 characters. The discovery of an endemic new species of lizards from the Garo Hills further highlights the region as an overlooked centre of biodiversity importance. We discuss several misidentifications in the literature of other reptile species from the region emphasising the need for further attention by taxonomists to review the herpetofauna of the Garo Hills.
\end{abstract}

Keywords: Biodiversity, taxonomy, lizard, reptile, endemic

\section{INTRODUCTION}

$\mathrm{T}$ he Bent-toed geckos of the genus Cyrtodactylus Gray, 1827 represent the most species-rich radiation of squamates with more than 300 species known to date (Grismer et al., 2021). Cyrtodactylus species range from Pakistan, throughout south and south-east Asia, the Indo-Australian Archipelago to northern Australia (e.g., Annandale, 1913; Darevsky et al., 1998; Mahony \& Reza, 2008; Mahony et al., 2009a, 2009b; Wood et al., 2012; Das et al., 2016; Agarwal et al., 2018b; Grismer et al., 2018b; Riyanto et al., 2018; Davis et al., 2019; Wang et al., 2020). Until recently, north-east India had only two reported species of Cyrtodactylus, $C$. gubernatoris (Annandale, 1913), known from only two specimens collected in the Darjeeling hills of northern West Bengal State, and C. khasiensis (Jerdon, 1870), a species long considered to be widespread throughout north-east India and neighbouring regions of southern China, Bangladesh and northern/western Myanmar (Smith, 1935; Ahsan,
1998; Li, 2007). Mahony (2009) and Mahony et al. (2009a) reviewed the taxonomic status of specimens referred to $C$. khasiensis from Myanmar and Bangladesh respectively, concluding that these populations represent other superficially similar species. Agarwal et al. (2014) was the first to conduct molecular phylogenetic analyses on populations of $C$. khasiensis from north-east India, demonstrating that most represent deeply divergent lineages. Agarwal et al. (2018b, 2018c) reviewed the known valid and synonymised taxa from northeast India, formally described eight new species, and elevated a synonym and a subspecies to species level. Purkayastha et al. (2020a) described a new species, $C$. urbanus Purkayastha, Das, Bohra, Bauer and Agarwal, 2020a, from the suburbs of Assam's state capital city, Guwahati, and expanded the known morphological variation for the other Cyrtodactylus species reported from the city, C. guwahatiensis Agarwal, Mahony, Giri, Chaitanya and Bauer, 2018, further emphasising the high species-level diversity in the region. Most recently, Mirza 
et al. (2021) described C. arunachalensis Mirza, Bhosale, Ansari, Phansalkar, Sawant, Gowande and Patel, 2021, a widely distributed species from Arunachal Pradesh State. Thirteen, mostly range restricted species are now known to occur in north-east India (Jerdon, 1870; Annandale, 1906, 1913; Agarwal et al., 2018b, 2018c; Purkayastha et al., 2020a; Mirza et al., 2021), and all bar one, $C$. tripuraensis Agarwal, Mahony, Giri, Chaitanya and Bauer, 2018, are considered endemic to India (Al-Razi et al., 2018). In this paper we provide a taxonomic study on Cyrtodactylus populations from the East Garo Hills, West Garo Hills and Ri Bhoi districts of Meghalaya, resulting in the discovery of a new species of Cyrtodactylus from forested habitat in the Garo Hills (Fig. 1) and an additional population of $C$. urbanus from Ri Bhoi. Our study increases the known diversity of Cyrtodactylus in Meghalaya State to four species, and permits an expanded description of morphological variation for $C$. urbanus.

\section{MATERIALS \& METHODS}

Fieldwork and curation. Fieldwork was carried out by R.G. Kamei (RGK) at Daribokgre Village (East Garo Hills District), and Jangrapara Village, Tura and Rangsaggre Village (West Garo Hills District) between 4 and 28 June 2014, and at Saiden Village, Nongpoh (Ri Bhoi District) on 3 July 2014 (Fig. 1). GPS coordinates and elevation for collection localities were determined using a Garmin GPSMAP 62s. Collected specimens were humanely euthanised by injecting ca. $2 \%$ lidocaine solution into the body cavity, fixed in $5 \%$ aqueous formalin in the field, and subsequently washed for 24 hours in water before being transferred to $70 \%$ ethanol for long-term preservation. Prior to fixation, a muscle tissue sample from the pectoral region was excised and stored in PCR grade absolute $\mathrm{EtOH}$ at $-4{ }^{\circ} \mathrm{C}$ for molecular analyses. After morphological examination, specimens were deposited at the Bombay Natural History Society, Mumbai, India (BNHS 2752-2756; BNHS 2852). Abbreviations used for other museum collections are as follows: Bernice Pauahi Bishop Museum, Honolulu, Hawaii, USA (BPBM); Brigham Young University, Provo, Utah, USA (BYU); California Academy of Sciences, San Francisco, California, USA (CAS); Centre for Ecological Sciences, Bangalore, India (CES); Chulalongkorn University Museum of Zoology, Bangkok, Thailand (CUMZ); Departmental Museum of Zoology, Mizoram University, Aizawl, Mizoram, India (MZMU); Field Museum of Natural History, Chicago, Illinois, USA (FMNH); La Sierra University Herpetological Collection, La Sierra University, Riverside, California, USA (LSUHC); Museum of Vertebrate Zoology, Berkeley, California, USA (MVZ); National Museum of Natural History, Smithsonian, Washington, USA (USNM); Natural History Museum, London, UK (NHMUK; previously British Museum [Natural History], BMNH); Pakistan Museum of Natural History, Islamabad, Islamabad Capital Territory (PMNH); North East Regional Centre, Zoological Survey India, Shillong, Meghalaya, India (NERC/ZSI; previously the Eastern Regional Station, Zoological Survey India, ERS/ZSI); Zoological Survey of India, Kolkata, West Bengal, India (ZSIK).
Molecular data. Genomic DNA was extracted using the DNeasy Blood and Tissue $\mathrm{Kit}^{\circledR}$ (Qiagen) following manufacturer's instructions. Partial sequences for $n d 2$ were amplified due to the extensive availability of homologous congeneric sequences available on GenBank (Benson et al., 2017) for phylogenetic reconstruction. Sequences were generated using either the primer pair L4437b and H5540 (Macey et al., 1997, 2000; ca. 1,010 nucleotides) or ND2-METF1 and ND2-COIR1 (Macey et al., 1997; 1,256 nucleotides). The PCR was performed in a $25 \mu \mathrm{l}$ reaction mix comprising of $1.5 \mu$ l extracted DNA ( 10 ng/ $\mu \mathrm{l}$ ), $10 \mu \mathrm{l}$ PCR grade $\mathrm{H}_{2} \mathrm{O}, 12.5 \mu \mathrm{l} \mathrm{MyTaq}{ }^{\mathrm{TM}}$ Mix (Bioline) and $0.5 \mu$ leach of forward and reverse primers $(10 \mathrm{ng} / \mu \mathrm{l})$. The PCR reaction protocol for the primers L4437b and $\mathrm{H} 5540$ was as follows: initial denaturation at $95{ }^{\circ} \mathrm{C}$ for two minutes, then 40 cycles of denaturation at $95{ }^{\circ} \mathrm{C}$ for 30 seconds, annealing at $53^{\circ} \mathrm{C}$ for 30 seconds, and extension at $72{ }^{\circ} \mathrm{C}$ for one minute. The final extension was at $72{ }^{\circ} \mathrm{C}$ for five minutes. The PCR reaction protocol for the primers ND2-METF1 and ND2-COIR1 was as follows: initial denaturation at $95{ }^{\circ} \mathrm{C}$ for three minutes, then 35 cycles of denaturation at $95{ }^{\circ} \mathrm{C}$ for 35 seconds, annealing at $50{ }^{\circ} \mathrm{C}$ for 35 seconds, and extension at 72 ${ }^{\circ} \mathrm{C}$ for 35 seconds. The final extension was at $72{ }^{\circ} \mathrm{C}$ for 10 minutes. PCR product purification and sequencing were outsourced to either Medauxin (Bangalore, India) or Barcode Biosciences (Bangalore, India). Sequence chromatograms were quality checked, edited and assembled into contigs using Geneious V.8.1.9 (Kearse et al., 2012). A BLAST (Altschul et al., 1990) search was performed on the NCBI BLAST website (http://blast.ncbi. $\mathrm{nlm}$.nih.gov) against GenBank sequences to verify their approximate identity. Newly generated sequences are available on GenBank (MW367435.1-MW367439.1; see Table 1). Comparative sequences (Table 1) comprising all members of the Indo-Burma radiation of Cyrtodactylus along with several outgroup taxa were obtained from GenBank, generated in the following studies: Siler et al. (2010); Johnson et al. (2012); Wood et al. (2012); Bauer et al. (2013); Agarwal et al. (2014, 2018c); Grismer et al. (2018a, 2018b, 2019a, 2019b); Muansanga et al. (2020); Purkayastha et al. (2020a). A sequence for $C$. myaleiktaung Grismer, Wood, Thura, Win, Grismer, Trueblood and Quah, 2018 was obtained directly from the original authors (Grismer pers. comm., 2020) as it was not available on GenBank at the time of writing. Sequence identities of some species were corrected following Mahony \& Kamei (in review). A sequence alignment was generated using MUSCLE (Edgar, 2004) on MEGA7 (Tamura \& Nei, 1993; Kumar et al., 2016) using default parameter settings. The alignment was converted from DNA to amino acid sequences to check for open reading frames and premature stop codons in the $n d 2$ sequences. Non-coding regions of the alignment were checked manually and adjusted where necessary. The total alignment length comprised 1,309 bp including the complete $n d 2+t R N A-t r p+t R N A$-ala + partial tRNAasn genes. Phylogenetic relationships were estimated with RAxML-HPC2 (Stamatakis, 2014) on XSEDE (CIPRES platform: Miller et al., 2010) for maximum likelihood, on an unpartitioned alignment dataset using the GTR CAT 
Table 1. List of Cyrtodactylus nd 2 sequences used in this study (newly generated sequences in bold). Museum abbreviations are defined and original citations for sequences given in the "Materials \& Methods" section. Dist. District; Subdist. Subdistrict; Div. Division; Reg. Region; Prov. Province; N.P. National Park; W.S. Wildlife Sanctuary; Mts. mountains. * specimen number and collection locality were recently corrected on GenBank by the original authors (Wood, Bauer \& Jackman pers. comm., 21/12/2020).

\begin{tabular}{l}
\hline Species \\
\hline C. annandalei Bauer, 2003 \\
C. arunachalensis Mirza, Bhosale, Ansari, \\
Phansalkar, Sawant, Gowande \& Patel, 2021 \\
C. aunglini Grismer, Wood, Thura, Win, Grismer, \\
Trueblood \& Quah, 2018c \\
${ }^{*}$ C. ayeyarwadyensis Bauer, 2003
\end{tabular}

\section{C. cf. ayeyarwadyensis}

C. battalensis Khan, 1993

C. bapme sp. nov.

C. bapme sp. nov.

C. bapme sp. nov.

C. bapme sp. nov.

C. bhupathyi Agarwal, Mahony, Giri, Chaitanya \& Bauer, 2018b

C. brevidactylus Bauer, 2002

C. chamba Agarwal, Khandekar \& Bauer, 2018c

C. chanhomeae Bauer, Sumontha \& Pauwels, 2003

C. chrysopylos Bauer, 2003

C. fasciolatus (Blyth, 1861)

C. cf. fasciolatus 1

C. cf. fasciolatus 2

C. gansi Bauer, 2003

C. gubernatoris (Annandale, 1913)

C. guwahatiensis Agarwal, Mahony, Giri, Chaitanya \& Bauer, 2018c

C. himalayanus Duda \& Sahi, 1978

C. jaintiaensis Agarwal, Mahony, Giri, Chaitanya \& Bauer, 2018c

C. kazirangaensis Agarwal, Mahony, Giri, Chaitanya \& Bauer, 2018c

C. khasiensis (Jerdon, 1870)

C. lawderanus (Stoliczka, 1871)

C. meersi Grismer, Wood, Quah, Murdoch, Grismer, Herr, Espinoza, Brown \& Lin, 2018b

C. mombergi Grismer, Wood, Quah, Thura, Herr \& Lin, $2019 b$

C. cf. mombergi

C. montanus Agarwal, Mahony, Giri, Chaitanya \& Bauer, 2018c

C. montanus Agarwal, Mahony, Giri, Chaitanya \& Bauer, 2018c

C. myaleiktaung Grismer, Wood, Thura, Win, Grismer, Trueblood \& Quah, 2018c

C. myintkyawthurai Grismer, Wood, Quah, Murdoch, Grismer, Herr, Espinoza, Brown \& Lin, 2018b

C. myintkyawthurai (erroneously as C. "feae" on GenBank)

C. nagalandensis Agarwal, Mahony, Giri,

Chaitanya \& Bauer, 2018c

C. novaeguineae (Schlegel, 1837)

C. nyinyikyawi Grismer, Wood, Thura, Win \& Quah, 2019a

C. peguensis (Boulenger, 1893)

C. philippinicus (Steindachner, 1867)

C. pyadalinensis Grismer, Wood, Thura, Win \& Quah, 2019a

\begin{tabular}{clc} 
Museum No. & Locality & $\begin{array}{c}\text { GenBank } \\
\text { Accession No. }\end{array}$ \\
\hline CAS 215722 & Myanmar, Sagaing Div., Alaungdaw Kathapa N.P. & JX440524.1 \\
CES13/1465 & India, Arunachal Pradesh State, Changlang Dist., Glow Lake. & KM255193.1
\end{tabular}

LSUHC 13948 Myanmar, Mandalay Reg., Pyin Oo Lwin Dist., Kyauk Nagar Cave.

MH764589.1

CAS 212459 Myanmar, Ayeyarwady Div., vicinity of Mwe Hauk Village

[previously as [previously as "Myanmar, Rakhine State, Than Dawe Dist., Gwa

“CAS 216459"] Township"].

CAS 216446 Myanmar, Rakhine State, vicinity of Kantheya Beach.

JX440526.1

PMNH 2301 Pakistan, North-West Frontier Prov., Battagram City.

GU550715.1

KC151983.1

BNHS 2752 India, Meghalaya State, East Garo Hills Dist., Daribokgre Hamlet.

MW367437.1

BNHS 2754 India, Meghalaya State, West Garo Hills Dist., Jangrapara Village.

BNHS 2755 India, Meghalaya State, West Garo Hills Dist., Tura Peak.

MW367438.1

MW367436.1

MW367435.1

KM255204.1

BNHS 2255 India, West Bengal State, Kalimpong Dist., near Lower Mongpong.

CAS 214105 Myanmar, Mandalay Reg., Popa Mountain Park.

GU550714.1

CES11/1291 India, Himachal Pradesh State, Chamba Dist., near Chamba.

KM255191.1

CUMZ 2003.62 Thailand, Saraburi Prov., Phraputthabata Dist., Khun Khlon Subdist., Thep Nimit Cave.

LSUHC 13937 Myanmar, Shan State, Taunggyi Dist., Ywnagan Township.

CES11/1337 India, Himachal Pradesh State, Shimla Dist., near Subathu.

CES11/1345 India, Uttarakhand State, Almora Dist., Almora.

CES09/1196 India, Uttarakhand State, Dehradun Dist., Mussoorie-Kempty Road.

CAS 222412 Myanmar, Chin State, Min Dat Township.

BNHS 2207 India, Sikkim State, East Sikkim Dist., Singtam Town.

BNHS 2146 India, Assam State, Guwahati Dist., Guwahati.

CES11/1317 India, Jammu and Kashmir State, Kishtwar Dist., near Kishtwar.

BNHS 2248 India, Meghalaya State, Jaintia Hills Dist., near Jowai.

BNHS 2147 India, Assam State, Golaghat Dist., Kohora.

JX440529.1

$\mathrm{MH764604.1}$

KM255184.1

KM255169.1

KM255172.1

JX440537.1

KM255181.1

KM255194.1

KM255187.1

KM255195.1

KM255170.1

BNHS 2249 India, Meghalaya State, East Khasi Hills Dist., Cherrapunjee Resort.

KM255188.1

KM255189.1

MH624104.1

LSUHC 13455 Myanmar, Bago Reg., Yangon (north) Dist., Taikkyi Township.

MN059875.1

LSUHC 14734 Myanmar, Kachin State, Mohnyin Township, Indawgyi W.S.

MN059869.1

LSUHC 14591 Myanmar, Kachin State, Mohnyin Township, Indawgyi W.S.

BNHS 2231 India, Tripura State, North Tripura Dist., Phuldungsei Village.

KM255200.1

MZMU 1630 India, Mizoram State, Dampa Tiger Reserve, Pathlawi Lunglen Tlang.

MT250544.1

LSUHC13965 Myanmar, Mandalay Reg., Mandalay Dist., Mya Leik Taung.

Grismer pers. comm., 17/10/2020

MH624107.1

JX440536.1

KM255199.1

JX440547.1

MH624118.1

MH756190.1

JX440550.1

MK488057.1 


\begin{tabular}{|c|c|c|c|}
\hline Species & Museum No. & Locality & $\begin{array}{c}\text { GenBank } \\
\text { Accession No. }\end{array}$ \\
\hline $\begin{array}{l}\text { C. pyinyaungensis Grismer, Wood, Thura, Zin, } \\
\text { Quah, Murdoch, Grismer, Lin, Kyaw \& Lwin, } \\
2018 \mathrm{~d}\end{array}$ & BYU 52234 & $\begin{array}{l}\text { Myanmar, Mandalay Reg., } 5.3 \mathrm{~km} \text { north of Pyinyaung Village at } \\
\text { the Apache Cement Factory mining site. }\end{array}$ & MF872307.1 \\
\hline C. russelli Bauer, 2003 & CAS 226137 & Myanmar, Sagaing Div., Htamanthi W.S. & JX440555.1 \\
\hline $\begin{array}{l}\text { C. septentrionalis Agarwal, Mahony, Giri, } \\
\text { Chaitanya \& Bauer, 2018c }\end{array}$ & BNHS 1989 & India, Assam State, Bongaigaon Dist., near Abhayapuri. & MH971164.1 \\
\hline C. slowinskii Bauer, 2002 & CAS 210205 & Myanmar, Sagaing Div., Alaungdaw Kathapa N.P. & JX440559.1 \\
\hline C. tibetanus (Boulenger, 1905) & MVZ 233251 & China, Tibet Autonomous Region, Lhasa, $3 \mathrm{~km}$ from of Potala Palace. & JX440561.1 \\
\hline $\begin{array}{l}\text { C. tripuraensis Agarwal, Mahony, Giri, Chaitanya } \\
\text { \& Bauer, } 2018 \mathrm{~b}\end{array}$ & BNHS 2238 & India, Tripura State, Sepahijala Dist., Sepahijala W.S. & KM255183.1 \\
\hline C. cf. tripuraensis & BNHS 2230 & India, Tripura State, North Tripura Dist., Rowa W.S. & KM255201.1 \\
\hline $\begin{array}{l}\text { C. urbanus Purkayastha, Das, Bohra, Bauer \& } \\
\text { Agarwal, 2020a }\end{array}$ & VR/ERS/ZSI/688 & $\begin{array}{l}\text { India, Assam State, Kamrup Metropolitan Dist., Guwahati, } \\
\text { Basishta Temple. }\end{array}$ & MN911174.1 \\
\hline C. urbanus & BNHS 2852 & India, Meghalaya State, Ri Bhoi Dist., Saiden. & MW367439.1 \\
\hline C. sp. Changlang1 & CES11/1349 & India, Arunachal Pradesh State, Changlang Dist., Miao. & KM255179.1 \\
\hline C. sp. Changlang2 & CES13/1459 & India, Arunachal Pradesh State, Changlang Dist., Miao. & KM255192.1 \\
\hline C. sp. Khellong & CES13/1464 & India, Arunachal Pradesh State, West Kameng Dist., Khellong. & KM255196.1 \\
\hline C. sp. Magway & LSUHC 226139 & Myanmar, Magway Reg., Min Bu Township, Shwesettaw W.S. & MH624118.1 \\
\hline C. sp. Mizoram & CES13/1455 & India, Mizoram State, near Aizawl Town. & KM255197.1 \\
\hline
\end{tabular}

model under default settings for 1,000 rapid bootstrap (bs.) replicates. The resulting phylogenetic tree was visualised in FigTree (Rambaut, 2009), and rooted with Cyrtodactylus tibetanus (Boulenger, 1905) which has previously been resolved as the sister taxon to remaining Cyrtodactylus species (e.g., Wood et al., 2012; Agarwal et al., 2014).

Morphology. Measurements were made using a Mitutoyo $^{\mathrm{TM}}$ digital calliper and rounded to the nearest $0.1 \mathrm{~mm}$. Measurements and scale counts were made on the right side of the specimens unless otherwise stated. Abbreviations and terminology used are as follows: SVL, snout to vent length; TRL, trunk length; BW, maximum body width; TL, tail length; TW, tail width taken on the first tail segment; TD, tail depth taken on the first tail segment; $H L$, head length from the snout tip to the retroarticular process of the jaw; $\mathrm{HW}$, maximum head width; JW, jaw width taken ventrally at the retroarticular process of the jaw; HD, maximum head depth; FL, forearm length; $C L$, crus length; $O D$, orbit diameter taken horizontally between the bony orbital borders (not equivalent to eyeball diameter); NO, distance between the posterior edge of the nostril and the anterior orbital border; SO, distance between the snout tip and the anterior orbital border; $\mathrm{OE}$, distance between the posterior orbital border and the anterior border of the ear; EL, maximum ear length/diameter; ES, anterior border of the ear to the snout tip; IN, internarial distance; 10 , minimum interorbital distance between the left and right supraciliary rows; FW, minimum frontal width; RL, maximum rostral length; RW, maximum rostral width; $M L$, maximum mental length; MW, maximum mental width; PMIL, maximum length of the inner postmental; PMIIL, maximum length of the outer postmental; FIVL, length of digit IV of the manus, from the proximal apex with digit III to the tip (excluding the claw); TIVL, length of digit IV of the pes, from the proximal apex with digit III to the tip (excluding the claw); PcP, precloacal pores, a continuous series of pore-bearing scales on the precloacal region that does not extend onto the thighs; PcFP, precloacofemoral pores, a continuous series of pore-bearing scales that extends from the precloacal region onto the thighs; FP, femoral pores, a series of pore-bearing scales on the thighs that are separated from a PcP/PcFP series by a diastema of non-pore-bearing scales; PCS, post cloacal spurs; MVSR, mid-ventral scale rows, counted between the ventrolateral folds; PVT1, paravertebral tubercles, counted from the most anterior tubercle on the occiput to the mid-sacrum; PVT2, paravertebral tubercles on the trunk only, counted between the level of the axilla and the level of the groin; DTR, dorsal tubercle rows, counted transversely across the trunk at its widest point; SL, total supralabials; IL, total infralabials. Two separate series for subdigital lamellae were counted on all digits of the right manus and right pes, a basal series, that includes scales of a width at least twice the diameter of the palmar scales up to and including a single large scale at the digital inflection, and an apical series, including lamellae distal to the digital inflection and not including the ventral claw sheath or nonlamellar scales between the basal and apical lamellae series (counted separately), abbreviated as follows: on manus, FILam, FIILam, FIIILam, FIVLam, FVLam; on pes, TILam, TIILam, TIIILam, TIVLam, TVLam. The morphological variation sections are based on the comparison of each paratype against the full original description of the holotype to determine variation within the species. The new species is compared morphologically with the following taxa that comprise all known species from the khasiensis clade (Lowland clade of Agarwal et al., 2014) of the khasiensis group (sensu Grismer et al., 2021) and other species from north-east India and surrounding countries that have not yet been included in a molecular phylogenetic study and so their systematic placement is currently unknown (marked with ${ }^{*}$ ): $C$. ayeyarwadyensis Bauer, 2003; ${ }^{*}$ C. cayuensis $\mathrm{Li}, 2007$; C. guwahatiensis; ${ }^{*}$ C. himalayicus (Annandale, 1906); C. kazirangaensis Agarwal, Mahony, Giri, Chaitanya \& Bauer, 2018; C. khasiensis; *C. mandalayensis Mahony, 2009; *C. 


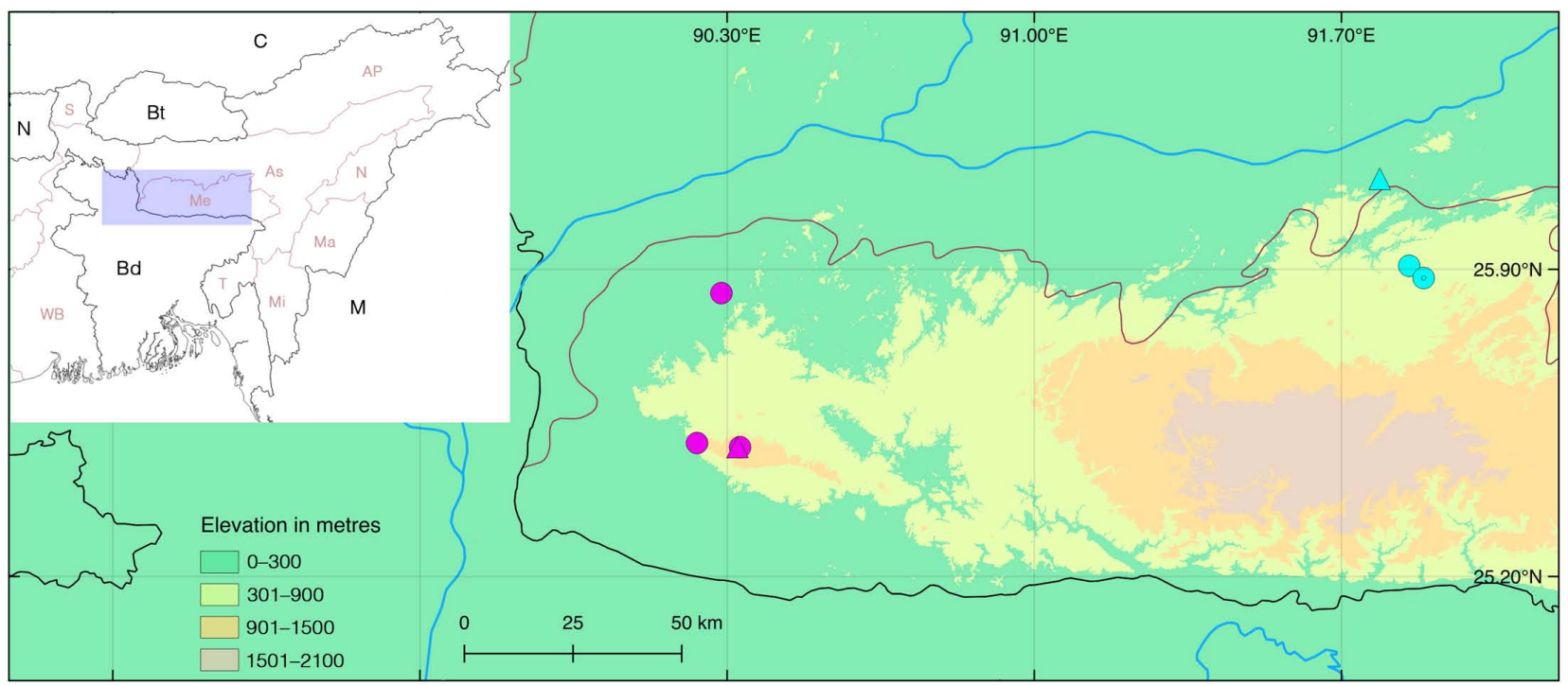

Figure 1. Topographic map of the Garo and Khasi Hills of Meghalaya State and bordering areas of Assam State, north-east India showing the distribution of Cyrtodactylus bapme sp. nov. and verified localities of $C$. urbanus: triangles represent the type localities; spots represent additional localities; cyan for $C$. urbanus; pink for Cyrtodactylus bapme sp. nov. Inset: map of north-east India with purple box representing the area depicted in the main map. Country borders in black; Indian state borders in brown; major rivers in blue; N Nepal; Bd Bangladesh; Bt Bhutan; C China; M Myanmar; As Assam; AP Arunachal Pradesh; Ma Manipur; Me Meghalaya; Mi Mizoram; N Nagaland; S Sikkim; T Tripura; WB West Bengal.

markuscombaii (Darevsky, Helfenberger, Orlov \& Shah, 1998); *C. martinstollii (Darevsky, Helfenberger, Orlov \& Shah, 1998); C. septentrionalis Agarwal, Mahony, Giri, Chaitanya \& Bauer, 2018; *C. tamaiensis (Smith, 1940); C. tripuraensis, and $C$. urbanus. Morphological characters cited for congeners in the comparisons sections are taken directly from either their original descriptions (i.e., Darevsky et al., 1998; Bauer, 2003; Li, 2007; Mahony, 2009; Agarwal et al., 2018b, 2018c; Purkayastha et al., 2020a), literature that reviewed the species based on their type specimens for $C$. khasiensis and C. himalayicus (Agarwal et al., 2018b), C. guwahatiensis (Purkayastha et al., 2020a) and C. tamaiensis (Mahony, 2009), and/or direct examination of specimens (Appendix I).

The new species is known only from female specimens and thus does not have the often-useful diagnostic character of PcP (otherwise observed on male Cyrtodactylus from the region). On the females, these scales instead possess a shallow pit (in lieu of a true pore). The number of pitted scales on females when present is either the same as or less (but never higher) than found on males of other related species for which both males and females are known (Agarwal et al., 2018b, 2018c), thus the total number of pitted scales in the precloacal series in females of the new species are considered indicative of the minimum number of PcP that would be expected on males of this species (see Bauer, 2003:488, 492, for similar discussion on the use of female PcP counts in morphological comparisons with males of other species). The comparison section of the species account therefore includes a comparison of female pitted precloacal scale number for the new species with PcP counts of males of related taxa for which information is not available in the original description whether females possess pitted scales, e.g., both Bauer (2003: for C. ayeyarwadyensis) and Darevsky et al. (1998: for C. markuscombaii \& C. martinstollii) state only that pores are absent on females, Purkayastha et al. (2020a: for C. guwahatiensis) does not mention whether pores or pits are present on females. Measurements and meristics for the juvenile paratype (BNHS 2756) were not taken.

Map. GPS coordinates of localities depicted on the distribution map were converted to Decimal Degrees (DD) format using GPS Visualizer (https://www.gpsvisualizer. com/calculators); coordinate system used throughout is DD format. The topographic map was made using Quantum GIS (QGIS v.2.14.3-Essen) using the $250 \mathrm{~m}$ spatial resolution Shuttle Radar Topography Mission (SRTM) layer available from DIVA-GIS (http://www. diva-gis.org), and other basic layers from the Natural Earth Quick Start Kit (http://www.naturalearthdata. com). The type locality for $C$. urbanus was plotted based on the revised GPS coordinates (see discussion in the "Cyrtodactylus urbanus distribution and morphological variation" section).

Additional notes. Within the comparison section, the elevational range of $C$. himalayicus was assessed based on data given in Agarwal et al. (2018b) for the type locality and the only known referred specimen from Gopaldhara Tea Estate (ZSIK 19546). The official Gopaldhara Tea Estate website (accessed 24/06/2020) gives the elevation range of the estate as 5,500-7,000 feet (converted to metres herein).

\section{RESULTS \& DISCUSSION}

The overall topology within the Indo-Burma radiation of Cyrtodactylus on the phylogenetic tree agrees well with those published elsewhere (e.g., Purkayastha et al., 2020a), with the exception of the placement of the clade 


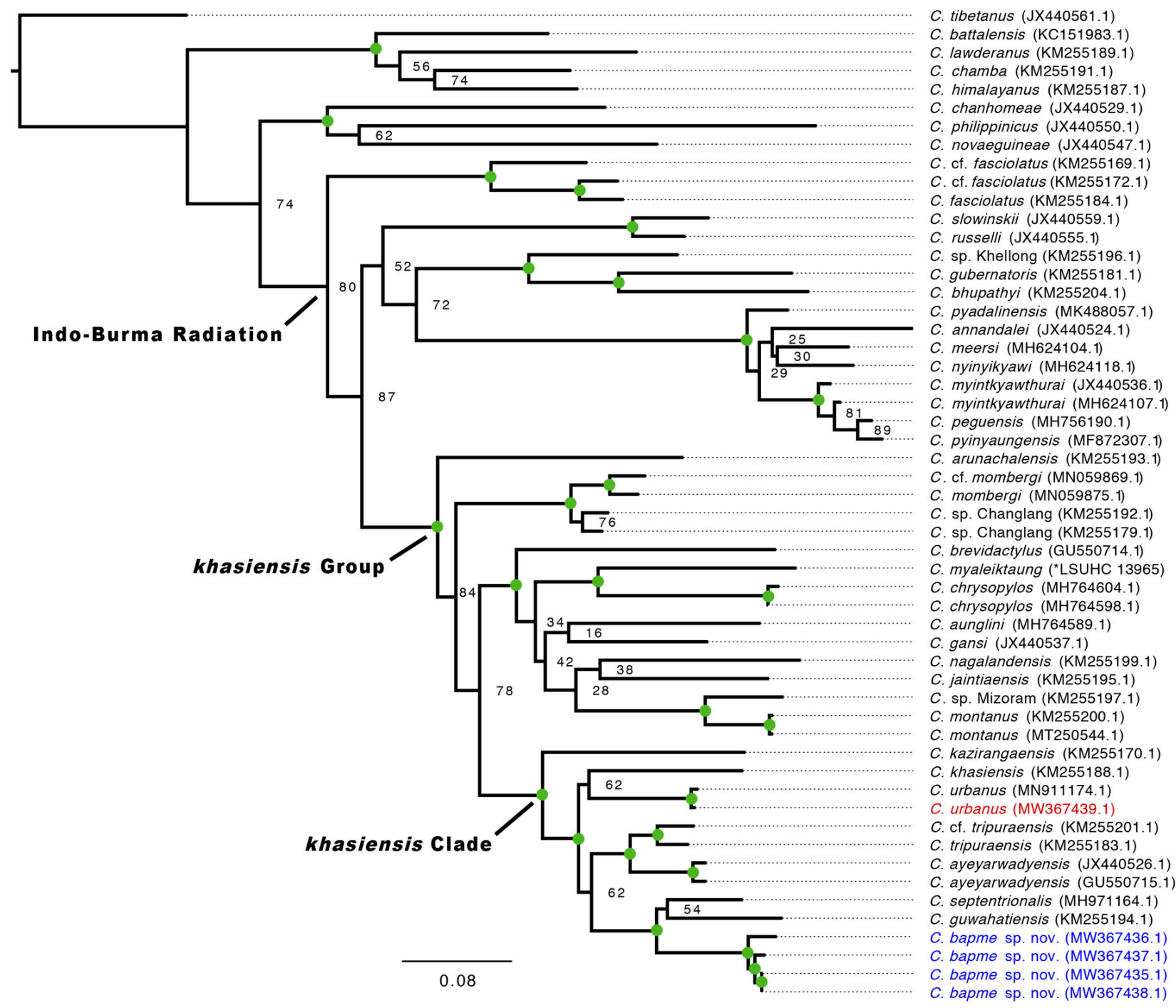

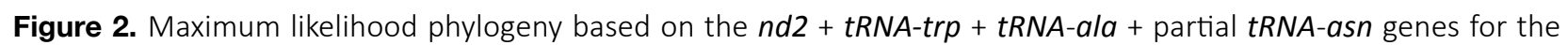
Indo-Burma radiation of Cyrtodactylus and outgroup taxa, showing the systematic position of the new Garo Hills species (blue) and newly discovered population of $C$. urbanus (red). GenBank numbers in parentheses (* specimen number). Bootstrap support values $\geq 95$ are represented by a green spot, values $<95$ are given next to relative nodes.

comprising C. russelli and C. slowinskii that is usually resolved as sister to a clade containing all Indo-Burma radiation taxa bar $C$. fasciolatus. However, the position of the russelli-slowinskii clade is often poorly resolved given similar taxonomic sampling (e.g., Purkayastha et al., 2020a). All newly generated sequences from populations sampled in the Garo Hills of Meghalaya formed a distinct clade. This Garo Hills clade is sister to a clade comprising $C$. septentrionalis and $C$. guwahatiensis with high support (bs. 100) (Fig. 2), which is nested within the khasiensis clade (Lowland clade of Agarwal et al., 2014) of the khasiensis group (sensu Grismer et al., 2021) in the Indo-Burma radiation of Cyrtodactylus. The sequence for the Saiden specimen was sister to a paratype (VR/ERS/ ZSI/688: Purkayastha et al., 2020a) of C. urbanus with sufficiently low divergence to be considered conspecific (Fig. 2; sequences $99 \%$ identical).

The morphological examination of the genetically distinct Garo Hills lineage demonstrated that it is diagnosable from other known species in the khasiensis clade, thus based on the combined morphological and molecular evidences, we consider the Garo Hills lineage to represent a distinct new species (described below).

\section{Systematics \\ Cyrtodactylus bapme sp. nov.}

\{urn:Isid:zoobank.org:pub:B1B43276-4E4D-46C1-BF437AB52FD5D137\}

Figs. 3-5; Table 2.

Holotype. Adult (gravid) female, BNHS 2752 (field number RGK 0435; Figs. 3E, F \& 4), from the banks of a stream below Daribokgre Wildlife Inspection Bungalow (25.494975, 90.323572, 1,015 $\mathrm{m}$ above sea level [asl.]), Daribokgre Hamlet, East Garo Hills District, Nokrek Ridge National Park in Nokrek Biosphere Reserve, Meghalaya State, north-east India, collected on 26 June 2014 by RGK.

Paratypes. Adult (gravid) female, BNHS 2753 (field number RGK 0486; Figs. 3D \& 5A), from Chibonga chiring (25.494721, 90.329413, 1,015 m asl.), Daribokgre Hamlet, East Garo Hills District, Nokrek Ridge National Park in Nokrek Biosphere Reserve, Meghalaya State, north-east India, collected on 28 June 2014 by RGK; an adult female, 
Table 2. Morphometric and meristic data for adult Cyrtodactylus bapme sp. nov. and referred specimen of $C$. urbanus. L/R data taken on left/right side; + incomplete tail; - data not taken. Refer to the "Materials \& Methods" section for explanation of abbreviations.

\begin{tabular}{|c|c|c|c|c|c|}
\hline \multirow[b]{2}{*}{ Specimen no. } & \multicolumn{4}{|c|}{ Cyrtodactylus bapme sp. nov. } & \multirow{2}{*}{$\begin{array}{l}\text { Cyrtodactylus urbanus } \\
\text { BNHS } 2852\end{array}$} \\
\hline & BNHS 2752 & BNHS 2753 & BNHS 2754 & BNHS 2755 & \\
\hline Status & Holotype & Paratype & Paratype & Paratype & Referred specimen \\
\hline Village & Daribokgre & Daribokgre & Jangrapara & Tura & Saiden \\
\hline Sex (maturity) & Female (adult) & Female (adult) & Female (adult) & Female (adult) & Male (subadult) \\
\hline SVL & 77.0 & 71.9 & 69.9 & 71.8 & 47.9 \\
\hline TRL & 33.1 & 33.8 & 33.0 & 30.6 & 20.7 \\
\hline BW & 16.2 & 15.7 & 11.4 & 16.9 & 10.6 \\
\hline TL & 88.2 & + & + & + & 55.4 \\
\hline TW & 7.1 & 5.4 & 5.9 & 5.8 & 3.9 \\
\hline TD & 6.6 & 5.2 & 5.2 & 5.1 & 3.3 \\
\hline $\mathrm{HL}$ & 21.5 & 19.6 & 18.6 & 19.3 & 13.2 \\
\hline HW & 15.8 & 13.8 & 12.5 & 14.0 & 9.2 \\
\hline JW & 14.0 & 11.5 & 11.8 & 12.5 & 8.6 \\
\hline$H D$ & 8.5 & 7.9 & 7.1 & 7.6 & 5.3 \\
\hline ES & 19.5 & 18.1 & 17.1 & 18.1 & 12.4 \\
\hline so & 8.6 & 7.6 & 7.4 & 7.5 & 5.1 \\
\hline $\mathrm{OE}$ & 6.3 & 5.6 & 5.1 & 5.6 & 3.3 \\
\hline NO & 6.6 & 5.9 & 5.9 & 5.7 & 4.0 \\
\hline OD & 6.2 & 6.0 & 5.7 & 6.0 & 4.1 \\
\hline EL & 1.6 & 1.9 & 1.2 & - & 1.2 \\
\hline IN & 2.7 & 2.6 & 2.3 & 2.6 & 1.6 \\
\hline FW & 3.2 & 3.0 & 3.1 & 3.0 & 2.0 \\
\hline 10 & 7.5 & 6.2 & 6.1 & 6.2 & 4.6 \\
\hline$R L$ & 2.2 & 2.1 & 1.8 & 2.0 & 1.1 \\
\hline RW & 3.3 & 3.2 & 3.1 & 3.4 & 2.2 \\
\hline $\mathrm{ML}$ & 2.4 & 1.9 & 1.9 & 2.2 & 1.4 \\
\hline MW & 3.2 & 3.0 & 3.0 & 3.0 & 2.3 \\
\hline PMIL & 2.3 & 2.2 & 2.2 & 2.2 & 1.3 \\
\hline PMIIL & 1.6 & 1.3 & 1.0 & 1.4 & 0.8 \\
\hline $\mathrm{FL}$ & 12.0 & 11.2 & 9.4 & 9.9 & 6.9 \\
\hline $\mathrm{CL}$ & 13.4 & 13.0 & 11.5 & 11.6 & 8.7 \\
\hline FIVL & 7.0 & 6.6 & 5.4 & 5.7 & 4.6 \\
\hline TIVL & 8.4 & 7.3 & 6.9 & 6.9 & 5.8 \\
\hline PcP & 0 [10 pitted] & 0 [10 pitted] & 0 [0 pitted] & 0 [13 pitted] & 13 \\
\hline FP & 0 & 0 & 0 & 0 & 0 \\
\hline $\operatorname{PCS}(\mathrm{L} / \mathrm{R})$ & $4 / 4$ & $3 / 3$ & $3 / 3$ & $4 / 4$ & $3 /-($ damaged) \\
\hline MVSR & 30 & 36 & $37-38$ & 39 & $\sim 39$ \\
\hline DTR & 23 & 23 & 21 & 24 & 20 \\
\hline PVT1 & $\sim 47$ & - & $49-51$ & $\sim 50$ & - \\
\hline PVT2 & $\sim 32$ & $\sim 32$ & $\sim 37$ & $\sim 35$ & $\sim 30$ \\
\hline$S L(L / R)$ & $9 / 8$ & $10 / 9$ & $11 / 10$ & $12 / 11$ & $12 / 11$ \\
\hline IL(L/R) & $9 / 8$ & $8 / 9$ & $8 / 10$ & $9 / 9$ & $11 / 10$ \\
\hline FILam & $3(3) 6[\mathrm{~L}]$ & $4(2) 5$ & $5(3) 4$ & $5(3) 6$ & $5(3) 6$ \\
\hline FIILam & $4(4) 7$ & $5(0) 9$ & $4(3) 6$ & $5(3) 7$ & $5(3) 7$ \\
\hline FIIILam & $5(3) 11$ & $5(1) 11$ & $5(4) 7$ & $5(3) 8$ & $5(2) 10$ \\
\hline FIVLam & $6(5) 8$ & $6(0) 13$ & $5(4) 7$ & $6(4) 7$ & $6(4) 9$ \\
\hline FVLam & $5(2) 9$ & $4(1) 9$ & $4(3) 6$ & $6(4) 6$ & $5(3) 8$ \\
\hline TILam & $4(4) 7$ & $4(3) 6$ & $4(4) 5$ & $4(3) 6$ & $4(4) 6$ \\
\hline TIILam & $5(3) 9$ & $6(1) 9$ & $5(3) 7$ & $5(4) 7$ & $5(2) 8$ \\
\hline TIIILam & $5(0) 14$ & $5(0) 12$ & $5(4) 8$ & $6(3) 11$ & $5(2) 10$ \\
\hline TIVLam & $8(0) 14$ & $6(0) 13$ & $7(5) 8$ & $7(4) 9$ & $6(3) 11$ \\
\hline TVLam & $6(1) 12$ & $5(1) 10$ & $6(3) 9$ & $6(3) 11$ & $4(3) 11$ \\
\hline Paired dark dorsal spots & $\sim 9$ & 7 & $\sim 9$ & $\sim 9$ & $\sim 9$ \\
\hline Dark tail bands & 10 & - & - & - & 13 \\
\hline
\end{tabular}




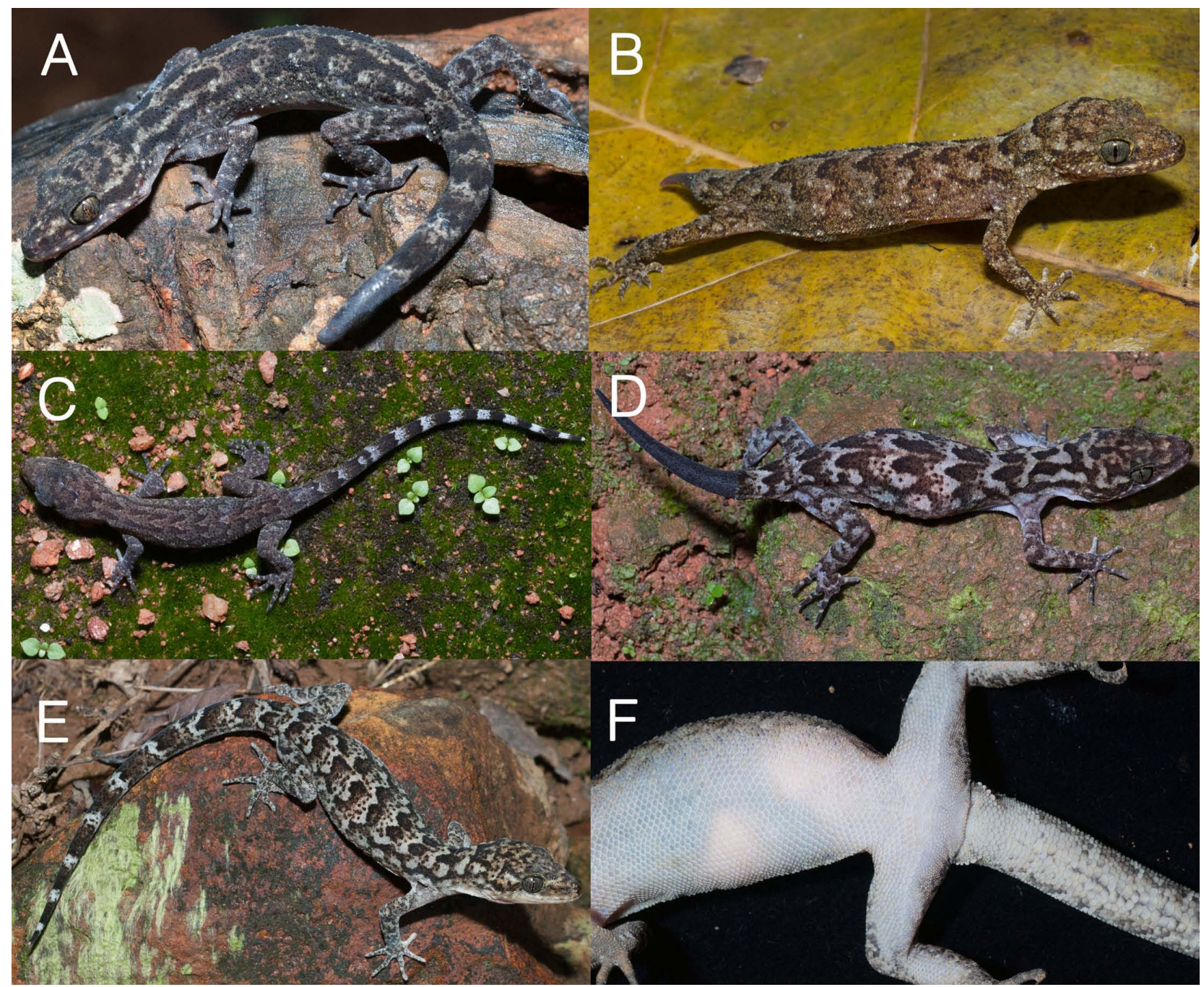

Figure 3. Cyrtodactylus bapme sp. nov. in life from Meghalaya State, north-east India, showing variation in colour and pattern: A. adult female paratype (BNHS 2754) from Jangrapara, West Garo Hills District; B. adult female paratype (BNHS 2755) from Tura Peak Reserved Forest, West Garo Hills District; C. juvenile paratype (BNHS 2756) from Jangrapara, West Garo Hills District; D. adult female paratype (BNHS 2753) from Daribokgre, East Garo Hills District; E. and F. adult female holotype (BNHS 2752) from Daribokgre, East Garo Hills District. Images taken ex-situ.

BNHS 2754 (field number RGK 0254; Figs. 3A \& 5C) and an unsexed juvenile, BNHS 2756 (field number RGK 0253; Fig. 3C), from a betel nut plantation close to the Public Works Department Inspection Bungalow (25.845801, 90.286975, $90 \mathrm{~m}$ asl.), Jangrapara Village, West Garo Hills District, Meghalaya State, north-east India, collected on 08 June 2014 by RGK; adult (gravid) female, BNHS 2755 (field number RGK 0413; Figs. 3B \& 5B), from the banks of Nengsandra dare Stream in Nikrang A'ding (25.504235, 90.231431, $750 \mathrm{~m}$ asl.), near a trail towards Tura Peak summit, Tura Peak Reserved Forest, Tura Hill Range, West Garo Hills District, Meghalaya State, north-east India, collected on 25 June 2014 by RGK.

Morphological character summary. Cyrtodactylus bapme sp. nov. is a moderate-sized gecko (SVL 69.9$77.0 \mathrm{~mm}$ ); 8-12 supralabials; 8-10 infralabials; dorsal tubercles are smooth to weakly keeled, bluntly conical; 21-24 dorsal tubercle rows; ca. 32-37 paravertebral tubercles between the level of the axilla and the level of the groin; 30-39 midventral scale rows; 0-13 pit-bearing (without true pore) precloacal scales in a continuous series in females, condition in males unknown; 12-19 subdigital lamellae on finger IV (excluding non-lamellar scales between the proximal and apical lamellae series); 15-22 subdigital lamellae on toe IV (excluding nonlamellar scales between the proximal and apical lamellae series); no single row of transversely enlarged subcaudal scales; 7-9 paired dark brown dorsal blotches on the dorsum; 10-12 alternating dark and light bands on the dorsum of the tail.

Holotype description (Figs. 3E, F \& 4). Holotype in generally good preservation condition, except for a portion of skin and muscle tissue removed from the right pectoral region as a tissue voucher.

Adult female (SVL $77.0 \mathrm{~mm}$ ), habitus robust (BW/ SVL 0.21; TRL/SVL 0.43), dorsoventrally depressed. Head moderately long (HL/SVL 0.28), dorsoventrally depressed (HD/HW0.54), distinctfrom neck; occipital regionenlarged relative to the jaw width (JW/HW 0.89); loreal region convex; interorbital area flat; canthus rostralis rounded; narrow longitudinal furrow medially on the snout is absent; snout short (SO/HL 0.40), longer than the orbit 
diameter (OD/SO 0.72); scales on the dorsal surfaces of the head, eyelids and snout are primarily homogeneous in size and shape, granular, longitudinally oval to circular, juxtaposed, those on the snout largest; granular scales on the occipital region and the rear of the head intermixed with sparse larger, rounded, bluntly pointed tubercles, smallest and sparse dorsally on the occipital region, increasing in size laterally over the occipital region and posteriorly onto the nape where they are three times larger than adjacent granules; enlarged tubercles are absent on the parietal and frontal regions of the head; orbits are moderately large (OD/HL 0.29); pupils vertical with crenulated margin; supraciliaries large, mucronate, largest bluntly pointed, smaller posterior supraciliaries sharply pointed and protruding laterally, decreasing in size towards the posterior and anterior end of the orbits, largest about one-third the way from the anterior edge of the orbits; a row of three slightly enlarged blunt tubercles parallel to the supraciliaries on the anterior outer upper eyelids; ear openings oval, obliquely orientated, small (EL/HL 0.07); orbit to ear distance is almost equal to the orbit diameter (OE/OD 0.98); rostral is wider than deep, divided dorsally to ca. half of the rostral depth by a weak rostral groove; a single enlarged supranasal on either side, separated by two small granular internasals; rostral is in contact with first supralabials, nasals, supranasals and two internasals; nostrils oval, openings directed postero-laterally, posterior half of the nasal is covered by the nasal pad, each nasal in broad contact with the rostral and surrounded by the supranasal, first supralabial, and four/five (left/right side) small postnasals; mental is wider than long, triangular; two well-developed postmentals on either side, inner pair in broad contact behind the mental, less than twice the size of and separating the outer pair from each other; inner postmentals are bordered by the mental, first infralabials, outer postmentals and three slightly enlarged gular scales; outer postmentals are bordered by the inner postmental, first and second infralabials, three slightly enlarged and two much enlarged gular scales, the largest positioned laterally; supralabials (to the midorbital position), eight on each side; nine/eight (left/right) supralabials to the angle of the jaw; nine/ eight (left/right) infralabials, second to fifth infralabials are bordered by one or two rows of enlarged scales that increase in size anteriorly; gular scales are mostly small, granular, smooth, juxtaposed, homogeneous in size except those mentioned above and where they increase in size posteriorly on the throat becoming more imbricate.

Dorsal scales on the body are heterogeneous, mostly small rounded granular scales, intermixed with irregularly arranged, enlarged bluntly conical tubercles which are smooth to weakly keeled dorsally, becoming more conical and slightly smaller laterally towards the lower flanks; dorsal tubercles extend from the nape onto the tail base; tubercles on the nape are smaller than those of the dorsum, largest on the posterior dorsolateral region where they are ca. five times the size of adjacent granular scales; ca. 23 dorsal tubercles across the mid-dorsum; ca. 32 paravertebral tubercles between the axilla and the groin, ca. 47 from the nape to the mid sacral region; slightly enlarged tubercles separated by small scales on the ventrolateral folds, tubercles rounded (not pointed), ventrolateral folds weak; ventral scales smooth, cycloid, imbricate to subimbricate, much larger than dorsal scales; ca. 30 ventral scales between ventrolateral folds at mid-trunk; ten pit-bearing (without true pore) precloacal scales in a continuous shallow "V"shaped series, pit-bearing scales slightly larger than the anteriorly contacting ventral scales; one row of slightly enlarged scales between the precloacal pit-bearing scale series and the cloacal opening, largest at the apex of the "V"-shaped pit-bearing scale series and ca. 1.5 times larger than the adjacent pit-bearing scales; precloacal groove absent; two large well developed eggs are visible through the abdominal skin.

Fore and hind limbs slender (FL/SVL 0.16, CL/SVL 0.17); digits strongly inflected at each joint, all bearing a robust recurved claw; enlarged subdigital lamellae not scansorial, proximal(granular)distal lamellae formula for the right manus unless stated otherwise as follows: FILam 3(3) 6 (taken on the left side as FILam on the right side is incomplete), FIILam 4(4)7, FIIILam 5(3)11, FIVLam 6(5)8, FVLam 5(2)9, proximal(granular)distal lamellae formula for the right pes as follows: TILam 4(4)7, TIILam 5(3)9, TIIILam 5(0)14, TIVLam 8(0)14, TVLam 6(1)12; interdigital webbing is absent on the manus and pes; relative length of the digits: I $<\mathrm{V}<$ II $<$ IV $<$ III on the right manus, I $<$ II $<$ III $<$ V $<$ IV on the right pes; scales on the palms and soles smooth, raised, juxtaposed to subimbricate; scales on the forelimbs are heterogeneous in size and shape, the dorsal and ventral surfaces of the upper arms and the ventral surface of the forearms are covered with small granular, subimbricate to juxtaposed scales, scales on the dorsum of the forearms are more heterogeneous in size and intermixed with a few slightly enlarged blunt, scattered tubercles, grading to smooth, flat, imbricate scales on the lower dorsum of the forearms; scales on the hind limbs are heterogeneous in size and shape, dorsal part of the thighs and shanks with small, blunt granular scales intermixed with scattered, enlarged, bluntly conical, smooth tubercles, equally dense on the shanks and the thighs; preaxial portion of the thighs and ventral aspect of the hind limbs with enlarged, smooth, flat, imbricate scales approximately equal in size to the ventral scales, small, granular scales on the postaxial surface of the thighs with a clear border where granular and subimbricate scales transition; femoral pores and enlarged femoral scale series are absent.

Tail original, complete, slightly dorsoventrally depressed (TD/TW 0.93), slender, tapering; caudal segments are barely distinct proximally, indistinct distally; a few enlarged, flat and distinctly keeled tubercles are randomly scattered on the first three segments of the tail, remaining dorsal caudal scales smooth, flat, heterogeneous in size and shape, subimbricate, smallest middorsally, becoming larger on the lateral aspect; subcaudal scales smooth, subimbricate and heterogeneous in size, distinctly larger than dorsal scales, no enlarged transverse plates or distinct series of enlarged paired subcaudal scales; the second tail 


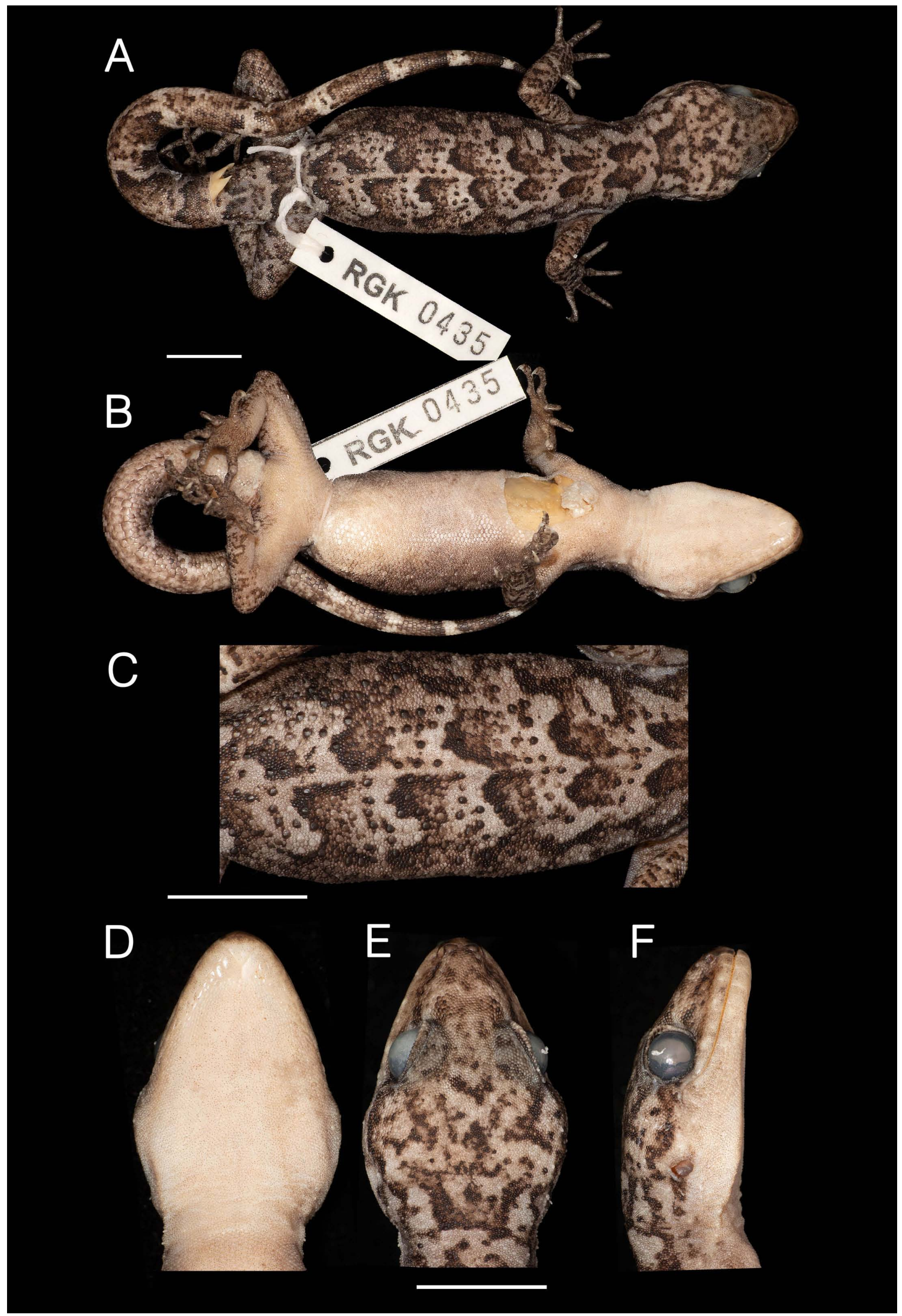

Figure 4. Cyrtodactylus bapme sp. nov. adult female holotype (BNHS 2752) in preservation: A. dorsal view; B. ventral view; C. details of dorsal pholidosis; D. dorsal view of head; E. ventral view of head; F. lateral view of head. $A$ and $B$ to scale; D-F to scale. Scale bar is $10 \mathrm{~mm}$. 


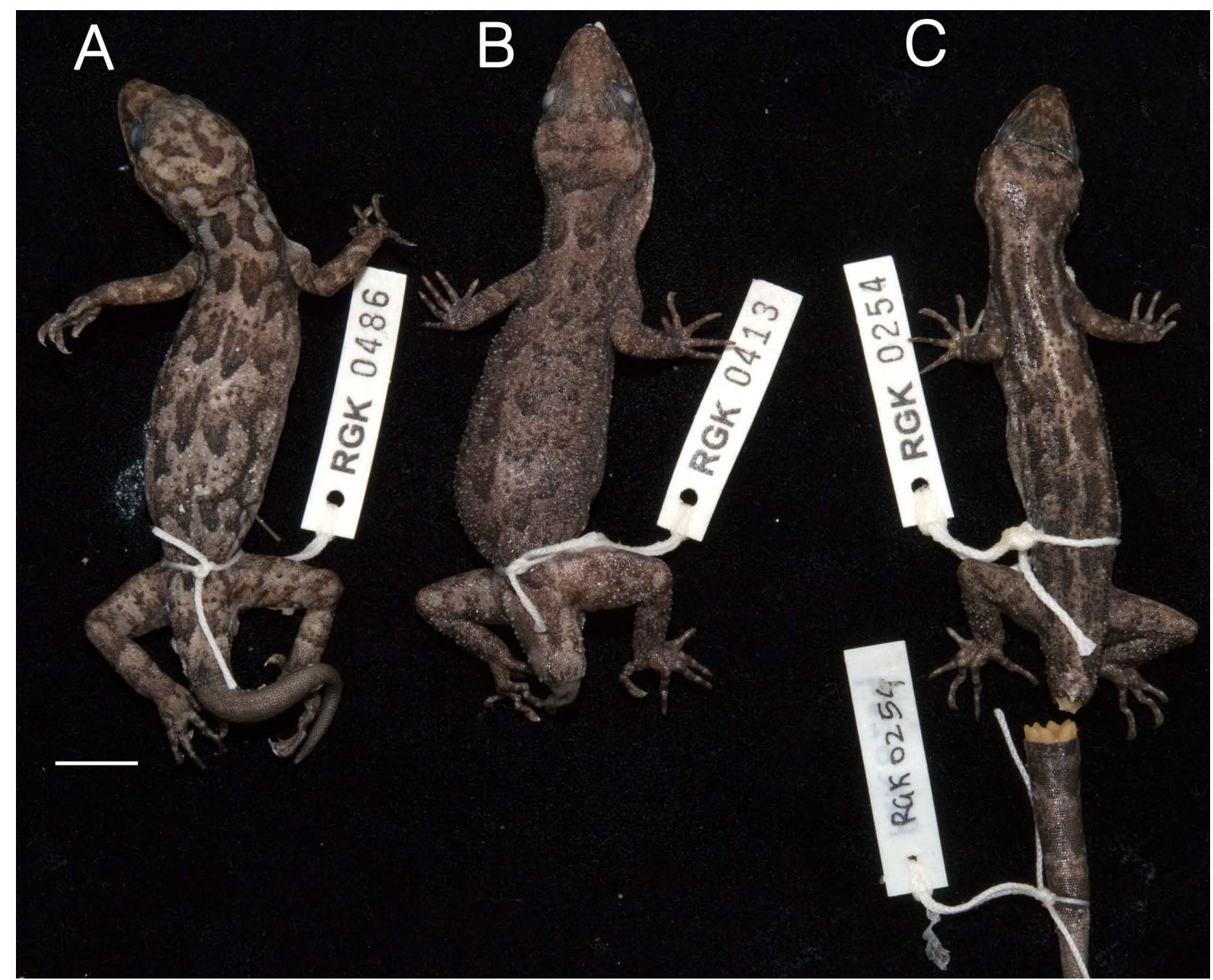

Figure 5. Cyrtodactylus bapme sp. nov. adult female paratypes in preservation from Meghalaya State, north-east India, showing variation of colour and pattern: A. BNHS 2753 from Daribokgre, East Garo Hills District; B. BNHS 2755 from Tura Peak Reserved Forest, West Garo Hills District; C. BNHS 2754 from Jangrapara, West Garo Hills District. Scale bar is $10 \mathrm{~mm}$.

segment with eight rows of scales dorsally reduced to four rows ventrally; four small, smooth post cloacal spurs on each side of the tail base.

Coloration in life (Fig. 3E, F): Dorsal and lateral surfaces of the head primarily light brown, densely mottled with dark brown, with pale greyish-brown supralabials and a dark brown rostral; anterior supraciliaries yellowishbrown becoming dark brown posteriorly; iris light grey with a brown venous pattern, pupil with a light grey border; dorsal and lateral surfaces of the neck and trunk are primarily light grey with nine pairs of dark brown blotches that are parallel anteriorly, becoming phaseshifted posteriorly; flanks with dark brown mottling; dorsal and lateral surfaces of the forelimbs and hind limbs mottled light grey and brown; tail, dorsally and laterally with ten contrasting dark brown and light grey transverse bands, light bands approximately half as wide as dark bands; entire ventral surface of the head, body and limbs white; ventral surfaces of the manus and pes are light greyish-brown to yellowish-brown; ventral surface of the tail primarily whitish proximally with brown mottling, becoming darker distally where the dark and light bands are distinct. Coloration in preservative (Fig. 4): generally similar to the coloration in life though less vibrant; ventrally the white in life darkened to pale brown, darker laterally on the abdomen and on the ventral surfaces of the manus and pes; iris dark grey; yellow tones on the supraciliaries faded to light brown.

Variation. Refer to Table 2 for morphometric and basic pholidosis variation within the type series of Cyrtodactylus bapme sp. nov., comprising four adult females. Additional details are given here for one unsexed juvenile paratype (BNHS 2756; Fig. 3C). The paratypes morphologically correspond with the holotype description, but with the following exceptions:

Head: 8-12 supralabials and 8-10 infralabials (Table 2); number of small gular scales posteriorly bordering the inner postmentals varies by individual: one or two granular scales on BNHS 2753 and BNHS 2755, and four on BNHS 2754; four or five small to large gular scales posteriorly border the outer postmentals on the paratypes; a narrow weakly developed longitudinal furrow is present medially on the snout of BNHS 2753, BNHS 2754 and BNHS 2755; internasals vary by number and size: one large internasal on BNHS 2753 and BNHS 2755, and three small granular internasals on BNHS 2754; rostral suture is ca. $60 \%$ of the 
rostral depth on BNHS 2754.

Tubercles: unlike the holotype, three paratypes (BNHS 2753, BNHS 2754, BNHS 2755) possess small densely packed tubercles on the parietal region; dorsal tubercle rows range $21-24$, and the number of paravertebral tubercles range ca. 32-37 between the level of the axilla and the level of the groin (Table 2); tubercles on BNHS 2754 are mostly conical on the body and limbs, with some weakly keeled on the posterior dorsum of the body; on BNHS 2755, tubercles are mostly conical on the anterior body and shanks, those on the mid-body and thighs have a weak median keel, those on the sacral region are more strongly keeled; some shank and thigh tubercles have a weak keel on BNHS 2753; largest dorsal tubercles are up to six times larger than the adjacent granular scale size on BNHS 2754; tubercles in the ventrolateral fold are bluntly spinose on BNHS 2754; dorsum of the forearms of BNHS 2754 with more dense tubercles than on the holotype; a row of slightly enlarged blunt tubercles run parallel to the supraciliaries on the anterior outer upper eyelids, varying as follows: the row absent on BNHS 2753, four or five tubercles in a row on BNHS 2754, and three or four tubercles in a row on BNHS 2755; post cloacal tubercle number varies as follows: three left and three right on BNHS 2753 and BNHS 2754, and four left and four right on BNHS 2755 (as on the holotype).

Body: ventrolateral folds are weakly defined on all specimens except on BNHS 2753 where the folds appear to be absent (possibly due to being heavily gravid); number of pit-bearing scales in the precloacal series varies from none to 13 (Table 2); the largest scale between the precloacal pit-bearing scale series and the cloacal opening varies as follows: ca. 1.3 times larger than adjacent pit-bearing scale size on BNHS 2753, ca. 1.5 times larger on BNHS 2755, and two times larger on BNHS 2754; midventral scale rows vary from 30 to 39 (Table 2); numbers of subdigital lamellae and presence/absence of non-lamellar scales between the proximal and distal portion of the digits varies considerably by individual (see Table 2).

Tail: second tail segment with nine transverse scale rows dorsally reduced to four ventrally on BNHS 2754; tubercles also extend to the third caudal segment on BNHS 2754 (as on the holotype); original tail is absent on BNHS 2753 and BNHS 2755.

Coloration and markings (Figs. 3-5): BNHS 2754, BNHS 2755 and BNHS 2756 have approximately nine pairs of dark brown dorsal blotches (as on the holotype), whereas BNHS 2753 has seven pairs; dark brown dorsal blotches are not phase-shifted on either side of the vertebral line on BNHS 2753, BNHS 2754, BNHS 2755 and BNHS 2756; complete original tail of BNHS 2756 has 12 dark brown blotches/bands, with alternating light and dark blotches/ bands less distinct proximally, light bands significantly narrower than dark bands proximally, but almost equal in width distally; regenerated tail portion of BNHS 2754, BNHS 2755 and BNHS 2753 is dark greyish-brown; in life, iris coloration varies from grey to greenish-grey; pupil with an orange border in BNHS 2754 in life; see Figures 3-5 for additional variation in colour and pattern between the holotype and paratypes.
Comparisons. Cyrtodactylus bapme sp. nov. is here compared with all known members of the khasiensis clade within the khasiensis group of Cyrtodactylus, including species not yet assigned to any clade due to the absence of available molecular data, i.e., C. cayuensis, C. martinstollii, C. markuscombaii, C. himalayicus, C. tamaiensis (see discussion in Mahony \& Kamei, in review).

Cyrtodactylus bapme sp. nov. can be diagnosed from C. ayeyarwadyensis by having dark dorsal spots not bordered posteriorly by white punctuations or a narrow white band, $\mathrm{N}=5$ (vs. "usually" bordered posteriorly by white punctuations or a narrow white band: Bauer, 2003), four subcaudal scale rows per segment on the original tail, $\mathrm{N}=4$ (vs. six on the holotype-variation not given by Bauer, 2003); from C. cayuensis by possessing up to 13 pit-bearing scales in the precloacal scale series in females indicating the likely minimum number of precloacal pores on males (vs. 6-9 PcPs in males, $N=9$ : Li, 2007), the largest scale at the apex of the precloacal pit-bearing scale series is between 1.3 and two times larger than the pit-bearing scales, $\mathrm{N}=4$ (vs. ca. 3 times larger than the pore-bearing scales on the holotype: determined from Li, 2007: fig. 3); from C. guwahatiensis by having a larger maximum adult body size, SVL $77.0 \mathrm{~mm}, \mathrm{~N}=4$ (vs. max. $70.5 \mathrm{~mm}, \mathrm{~N}=8$ : Agarwal et al., 2018c; Purkayastha et al., 2020a), dark dorsal spots not bordered posteriorly by white punctuations or a narrow white band, $\mathrm{N}=5$ (vs. bordered posteriorly by white punctuations on the holotype and other referred specimens: Agarwal et al., 2018c; Purkayastha et al., 2020a; Purkayastha pers. comm., 2020); from C. himalayicus by having a larger maximum adult body size, SVL $77.0 \mathrm{~mm}, \mathrm{~N}=4$ (vs. 64.5 $\mathrm{mm}, \mathrm{N}=2$ : Agarwal et al., 2018b; examined specimens), weak ventrolateral folds (vs. absent: Agarwal et al., 2018b; examined specimens), the largest scale at the apex of the precloacal pit-bearing scale series is between 1.3 and two times larger than the pit-bearing scales, $\mathrm{N}=4$ (vs. ca. 3 times larger than the pore-bearing scales, $\mathrm{N}=2$ : Agarwal et al., 2018b; examined specimens), elevational distribution limit of 90-1,015 m asl. (vs. ca. 1,525-2,130 m asl.: Agarwal et al., 2018b; Gopaldhara Tea Estate website, accessed 24/06/2020); from $C$. kazirangaensis by having tubercles extending to the third segment of the tail, $\mathrm{N}=3$ (vs. tubercles not extending beyond the first segment of the tail, $\mathrm{N}=2$ : Agarwal et al., 2018c), dorsal body pattern with 7-9 pairs of dark brown blotches, $\mathrm{N}=5$ (vs. dorsal pattern composed of six or seven irregular light and dark crossbars, $\mathrm{N}=3$ : Agarwal et al., 2018c), largest dorsal tubercles ca. 4-6 times larger than adjacent granular scales, $\mathrm{N}=4$ (vs. approximately three times larger than adjacent granular scales on the holotype: determined from Agarwal et al., 2018c: fig. 7c-variation for paratypes not given); from $C$. khasiensis by having distinctly enlarged scales between the pit-bearing precloacal scale series and the cloaca, $\mathrm{N}=4$ (vs. not enlarged relative to pore-bearing scales, $\mathrm{N}=6$ : examined specimens), a relatively wider mental scale, $\mathrm{ML} / \mathrm{MW}$ ratio $0.62-0.74, \mathrm{~N}=4$ (vs. $0.77-$ $0.96, \mathrm{~N}=4$ : examined specimens); from $C$. mandalayensis by having a greater number of dorsal tubercle rows, 
21-24 DTR, N=4 (vs. 18, N=1: Mahony, 2009; examined specimen), by possessing up to 13 pit-bearing scales in the precloacal scale series in females indicating the likely minimum number of precloacal pores on males, $N=4$ (vs. minimum $5+1$ [possibly up to eight] pores in the PcP series, $\mathrm{N}=1$ : Mahony, 2009; examined specimen); from $C$. markuscombaii by possessing up to 13 pit-bearing scales in the precloacal scale series in females indicating the likely minimum number of precloacal pores on males, $\mathrm{N}=4$ (vs. seven pore-bearing scales on the only known male, $\mathrm{N}=1$, condition in females unknown: Darevsky et al., 1998), dorsal body pattern with 7-9 pairs of dark brown blotches, $\mathrm{N}=4$ (vs. irregular transverse dark brown bands, $\mathrm{N}=2$ : Darevsky et al., 1998), elevational distribution limit of 90-1015 m asl. (vs. elevation 1200-1300 m asl.: Darevsky et al., 1998); from C. martinstollii by possessing up to 13 pit-bearing scales in the precloacal scale series in females indicating the likely minimum number of precloacal pores on males, $\mathrm{N}=4$ (vs. $0-8$ PcP on males, $\mathrm{N}=18$, condition in females unknown: Darevsky et al., 1998), dorsal body pattern with 7-9 pairs of dark brown blotches, $N=4$ (vs. densely mottled, ca. 10-11 paired blotches when distinguishable, $\mathrm{N}=4$ : determined from Darevsky et al., 1998: Fig. 1), elevational distribution limit of 90-1,015 m asl. (vs. 1200-1300 m asl.: Darevsky et al., 1998); from $C$. septentrionalis by having a larger maximum adult body size, SVL $77.0 \mathrm{~mm}, \mathrm{~N}=4$ (vs. max. $65.2 \mathrm{~mm}, \mathrm{~N}=2$ : Agarwal et al., 2018c), fewer paravertebral tubercles between the level of the axilla and the level of the groin, 32-37 PVT2, $\mathrm{N}=4$ (vs. 38-42 PVT2, N=2: Agarwal et al., 2018c); from $C$. tamaiensis by having a smaller maximum adult body size, SVL 77.0 mm, N=4 (vs. 90.0 mm, N=1: Mahony, 2009; examined specimen), dorsal tubercles extend posteriorly onto the third segment of the tail, $\mathrm{N}=3$ (vs. to the fourth segment, $\mathrm{N}=1$ : Mahony, 2009; examined specimen); from $C$. tripuraensis by having a larger maximum adult body size, SVL $77.0 \mathrm{~mm}, \mathrm{~N}=4$ (vs. max. $70.7 \mathrm{~mm}, \mathrm{~N}=11$ : Agarwal et al., 2018b), pit-bearing precloacal scale series in females comprises 0-13 scales, $\mathrm{N}=4$ (vs. 19-29 pitbearing scales or PcFP in the precloacal scale series of females, $N=4$ : Agarwal et al., 2018c), typically higher number of dorsal tubercle rows, 21-24, $\mathrm{N}=4$ (vs. 19-21, $\mathrm{N}=11$ : Agarwal et al., 2018c); from C. urbanus by having fewer apical subdigital lamellae on first finger, 4-6 (vs. 7-9, N=5: Purkayastha pers. comm., 2020).

Distribution and Natural History. This species is currently known from multiple low to mid elevation (90-1015 $\mathrm{m}$ asl) localities in the East and West Garo Hills districts (Fig. 1), of which the upper limits extend the maximum known elevation of the khasiensis clade from $900 \mathrm{~m}$ asl. for C. khasiensis (Agarwal et al., 2018b). Comparing with what is known of other north-east Indian Cyrtodactylus species, besides $C$. tripuraensis which has been reported from several localities in Tripura State (Agarwal et al., 2018b) and adjacent Bangladesh (AlRazi et al., 2018), and C. arunachalensis with a known distribution extending ca. $350 \mathrm{~km}$ along the Brahmaputra Valley (Mirza et al., 2021), Cyrtodactylus bapme sp. nov. is the third most widespread species of this genus in northeast India. All other north-east Indian Cyrtodactylus species are currently confirmed from only one or two localities (Agarwal et al., 2018b, 2018c; Purkayastha et al., 2020a, 2020c; herein).

BNHS 2755 was collected from a boulder on the bank of the Nengsandra dare (ca. 20:30 hours), an ephemeral stream in Nikrang A'ding near a trail towards Tura Peak (Tura Peak Reserved Forest). During other years surveyed (between 2008 and 2011), this stream becomes torrential in June which is the peak of south-west summer monsoon in north-east India. However, in 2014 it was relatively dry exposing more of the large boulders along the stream bank. The stream is surrounded on both sides by secondary forests with fairly dense undergrowth vegetation. BNHS 2754 and BNHS 2756 were collected from an indigenous agroforestry system called paan jhum (a practice of cultivating betel vine, Piper betle L.: e.g., Rahman et al., 2009; Nandy \& Das, 2013) at around 20:00 hours on a rainless night. BNHS 2754 was spotted by eyeshine from the trunk of an areca nut tree (or betel palm tree, Areca catechu L.) at approximately two metres above ground level. The jhum had broad-leaved trees including jackfruit tree (Artocarpus heterophyllus Lam.) which is extensively grown in the West Garo Hills District (Phaomei \& Mathew, 2019), and had a few fallen tree trunks and sparse herbaceous undergrowth. BNHS 2752, BNHS 2753 and BNHS 2755 each contain two large well developed eggs visible through the abdominal skin (e.g., Fig. 3D, F) indicating that egg-laying occurs during the monsoon season.

Etymology. The specific epithet "bapme" is derived from the word for "gecko" in the Garo language of the A'chik Mande ("Garo people"), the tribe indigenous to the region where the species occurs. The name is treated as a noun in apposition.

Suggested Common name. Garo Hills bent-toed gecko.

\section{Cyrtodactylus urbanus distribution and morphological variation.}

Cyrtodactylus urbanus was recently described based on a type series comprising seven specimens collected from "Basistha, Guwahati, Assam State, India $\left(26.106301^{\circ} \mathrm{N}, 91.787199^{\circ} \mathrm{E}\right), 106 \mathrm{~m}$ elevation above sea level" (Purkayastha et al., 2020a). The authors stated in the distribution section that the type series was collected "from around Basistha Temple", however, the GPS coordinates plotted in Google Maps (accessed $17 / 01 / 2021$ ) place the type locality within the relatively more developed suburb of Basistha, ca. $1.3 \mathrm{~km}$ north of Basistha Temple. The authors did not provide the district name in the type locality, although it was mentioned elsewhere in the table of sequences as "Kamrup (M) district" (Purkayastha et al., 2020a: table 1). We have subsequently confirmed that the holotype was collected from the Basistha Temple grounds (Purkayastha pers. comm., 27/03/2021) so we suggest the following revision of the type locality of $C$. urbanus: "Basistha Temple, Guwahati city, Kamrup Metropolitan District, Assam State, India (26.094846, 91.784545), 106 m elevation above sea level". Basistha Temple is situated on the border of Garbhanga Reserve Forest where the presence of $C$. urbanus is expected in contiguous 
habitat. Figure $6(C, D)$ shows an additional example of a live (uncollected) individual likely conspecific with $C$. urbanus from nearby Basistha Temple. This individual was observed at ca. 22:00 hours on a vertical path-side embankment adjacent a small seep and surrounded by dense foliage. Purkayastha et al. (2020a) mentioned that they possessed "photographic vouchers" of $C$. urbanus from "Deeporbeel, Garbhanga Reserve Forest, Gotanagar and Rani Reserve Forest" in the vicinity of Guwahati but they neither published the photo vouchers nor cited the digital repository/registration numbers for the photo vouchers. We encourage the original authors to provide verifiable evidence for the presence of $C$. urbanus from these localities; but for now, we recommend that these reserve forests are not included in the confirmed distribution of the species.

Purkayastha et al. (2020c) reported a range extension for C. urbanus into Meghalaya State, at Nongpoh ("25.9081 $\mathrm{N}, 91.8543^{\circ} \mathrm{E}$ "), Nongpoh Subdivision of Ri Bhoi District, less than $25 \mathrm{~km}$ straight distance from the type locality; the map in Purkayastha et al. (2020c: Fig. 2) erroneously depicted this locality a further ca. $30 \mathrm{~km}$ south of the coordinates they provided (see Fig. 1 for corrected distribution). The elevation (not mentioned in Purkayastha et al., 2020c) at this GPS location is ca. 680-700 $\mathrm{m}$ asl. (assessed on Google Maps), revising the confirmed elevational range of the species to $100-700 \mathrm{~m}$ asl. The authors identified the single female specimen based on a comparison of its $n d 2$ gene sequence with congeners ( $p$-distance $0.7-0.9 \%$ from $C$. urbanus from the type locality), but provided no morphological details. We herein report the third confirmed locality for $C$. urbanus based on a single subadult male specimen (BNHS 2852, field number RGK 0554) collected from Saiden Village (25.880219, 91.887277, $565 \mathrm{~m}$ asl.), Nongpoh Subdivision in Ri Bhoi District, Meghalaya State. This third locality lies ca. five kilometres south-east of Purkayastha et al.'s (2020c) Nongpoh locality, and ca. 26 km south-east of the type locality (Basistha Temple). The Ri Bhoi localities are adjacent to the Nongkhyllem Wildlife Sanctuary (29 $\mathrm{km}^{2}$ ) within the Nongkhyllem Reserve Forest (125.91 $\mathrm{km}^{2}$ ) and Umsaw Reserve Forest $\left(0.44 \mathrm{~km}^{2}\right)$; both are provided state-level protection by the Meghalaya Forest Department (online, accessed 24/11/2020: http://www. megforest.gov.in/). Mathew (1995) listed two specimens (specimen numbers not given) identified as $C$. khasiensis in the collection of NERC/ZSI from "Umtham" Village and "Barapani" ( 15-20 km south of Saiden) in Ri Bhoi District (localities erroneously reported to be in the East Khasi Hills District), Meghalaya. These localities are ca. $80 \mathrm{~m}$ higher in elevation than the Nongpoh population and are situated in contiguous habitat so may represent additional distribution records for $C$. urbanus. We recommend that these two specimens be re-examined to determine their species-level identifications.

Besides providing standard measurements and basic meristics for the type series of $C$. urbanus, Purkayastha et al. (2020a) did not provide any morphological variation section to accompany the description of the holotype. In the absence of a detailed morphological variation section for a given species, it is not possible to determine how much of a holotype description represents taxonomically relevant morphological characters for that species; holotypes are often arbitrarily selected specimens that do not necessarily show "typical" or representative morphological characters for the species. A detailed comparison of the newly collected specimen (BNHS 2852) with the holotype description of Purkayastha et al. (2020a), and characters mentioned elsewhere in the paper (or visible in figures) for the type series demonstrates that the newly collected specimen expands the known morphological variation of the species, as follows: 1) granular scales are intermixed with a few small tubercles on the parietal region of the head, increasing in size posteriorly and laterally (vs. "scales on interorbital and occipital regions heterogeneous, without distinct tubercles" on the holotype); 2) nostrils oval (vs. "nostrils semicircular" on the holotype); 3) inner postmental pair less than twice the size $(1.3 \mathrm{~mm})$ of the outer postmental pair $(0.8 \mathrm{~mm})$ (vs. "inner [postmental] pair more than twice the size $(2.6 \mathrm{~mm})$ of and separating outer [postmental] pair (1.0 mm)" on the holotype); 4) few distinctly pointed tubercles on the ventrolateral folds (vs. "enlarged, smooth tubercles" on the holotype); 5) dorsal tubercles mostly conical to bluntly pointed on the body and limbs, without a median keel (vs. "bluntly conical and feebly keeled throughout" on the holotype); 6) original tail is dorsoventrally depressed (vs. "Tail original, ... rounded in cross-section" on the holotype); 7) subcaudal scales enlarged and heterogeneous in size, do not form a distinct midventral series of paired scales (vs. "subcaudal scales ... with midventral series of paired scales" on the holotype); 8) no distinct light-coloured middorsal stripe (vs. "a mid-dorsal cream coloured line divides the trunk and extends posteriorly to the level of the cloaca" on the holotype); 9) 11 supralabials on the right side, 12 on the left side (vs. 9-11 according to the species' "Diagnosis" section, however, this contrasts with counts provided elsewhere in the paper, i.e., 8-11 in the type series, $\mathrm{N}=7$, according to table 4 ); 10 ) ten infralabials on the right side, 11 on the left side (vs. 8-10 in the type series, $\mathrm{N}=7$ ); 11) DTR 20 (vs. 21-24 according to the species' "Diagnosis" section, however, this contrasts with counts provided elsewhere in the paper, i.e., 22-24 in the type series, $N=7$, according to tables 4 \& 5); 12) MVSR 39 (vs. 30-34 in the type series, $N=7$ ); 13) PcP 13 (vs. 9-12 on males in the type series, $N=4) ; 14$ ) scale row posteriorly bordering the PCP row is slightly enlarged relative to the pore-bearing scales (vs. "no enlarged scales between precloacal pores and vent" on the holotype, however, their fig. $4 \mathrm{~B}$ depicting the $\mathrm{PcP}$ region of the holotype shows that the scale row posteriorly bordering the PcP row is distinctly enlarged relative to pore bearing scales and conflicting information was given in the species' "Diagnosis" stating "a row of enlarged scales above and below precloacal pore-bearing scales, slightly larger than pore-bearing scales"); 15) 13 dark brown transverse bands on the complete original tail (vs. "approximately 14 dark bands" stated in the species' comparison section, however, their figures 5 \& 8 show that the type series have 13 or 14 dark bands on the original tails, $\mathrm{N}=5$; however, the specimen reported in 
Purkayastha et al. [2020c: fig. 1] from Nongpoh has 11 dark bands on a complete original tail, so the known range for the species is now 11-14 dark bands on a complete original tail); 16) in life, iris dark green with brown reticulations and orange pupil border on the Saiden specimen, and emerald green with brown reticulations and light brown pupil border on the Basistha uncollected individual (Fig. 6) (vs. "Iris in life silver-grey with brown reticulations"); 17) total TIVLam 17 (vs. 1921 on the type series, $\mathrm{N}=7$ according to table 4 and the "comparisons" section, however, conflicting information is given in the holotype description that stated 18 TIVLam [7 basal + 11 distal lamellae], and the species' "Diagnosis" section gave the ranges $6-7$ basal and 10-12 distal lamellae, thus a maximum of 19 TIVLam in the species); 18) total FIVLam 15 (vs. 16-19 on the type series, $N=7$ according to table 4 , however, conflicting information is given in the holotype description that stated 15 FIVLam [ 6 basal + 9 distal lamellae], and the species' "Diagnosis" section gave the ranges 5-6 basal and 8-10 distal lamellae, thus a maximum of 16 FIVLam in the species). The "Materials \& Methods" section stated that the basal and apical lamellae series were counted separately, but did not mention whether non-lamellar scales between the basal and apical series were counted as apical lamellae in total counts, and the authors only provided the separate (basal and apical) counts for the holotype. We suggest that the authors of Purkayastha et al. (2020a) publish a table giving separate basal and apical lamellae counts, and intervening non-lamellar scale counts for all specimens in the type series to resolve this confusion; 19) PVT2 ca. 30 counted between the level of the axilla and the level of the groin (vs. PVT count for the holotype was reported in the holotype description as " 45 ", but in table 4 as "38". Three different PVT ranges were given for the species, i.e., "38-45" in the species' "Definition" section, "38-40" in the comparison section with $C$. khasiensis, and then "37-40" in tables 4 and 5). Purkayastha et al. (2020a) stated in the "Materials \& Methods" section that PVT counts were made as follows: "PVT, para vertebral tubercles (PVT, counted from the most anterior tubercle on the occiput to mid-sacrum)", however, the close-up figure of the trunk of the holotype of C. urbanus (Purkayastha et al., 2020a: fig. 5C) has sufficient resolution to count ca. 38 PVT between the level of the forelimb and hind limb insertions (a common alternative method for counting PVT in some studies: see Discussion in Mahony \& Kamei, in review). The authors are encouraged to clarify which numbers are correct for the PVT counts and accurately describe how the count was taken; 20) postcloacal tubercles, three on the left side, the region where spurs are generally found is damaged on the right side (vs. the presence and number of postcloacal spurs is not mentioned in Purkayastha et al., 2020). Purkayastha et al. (2020a: figs. 5 \& 8) show three postcloacal spurs are visible on the left and right sides of the holotype, and in their figure 8 , three are visible on the right side of paratypes VR/ERS/ZSI 685 and VR/ERS/ZSI 687, and three are visible on the left side of paratype VR/ERS/ZSI 686, demonstrating that males of this species typically possess at least three spurs on each side. Postcloacal spurs are not visible/discernible on the three female paratypes in their figure 8 (VR/ERS/ZSI/684, VR/ERS/ZSI/688, VR/ERS/ZSI/689), however, unpublished images provided to us (Purkayastha pers. comm., 2020) show three spurs of considerably reduced size (compared to males) are present on the three female specimens; 21 ) The presence or absence of PcP on females of $C$. urbanus is not clear from Purkayastha et al. (2020a) as it is not explicitly mentioned in the text. In the character table

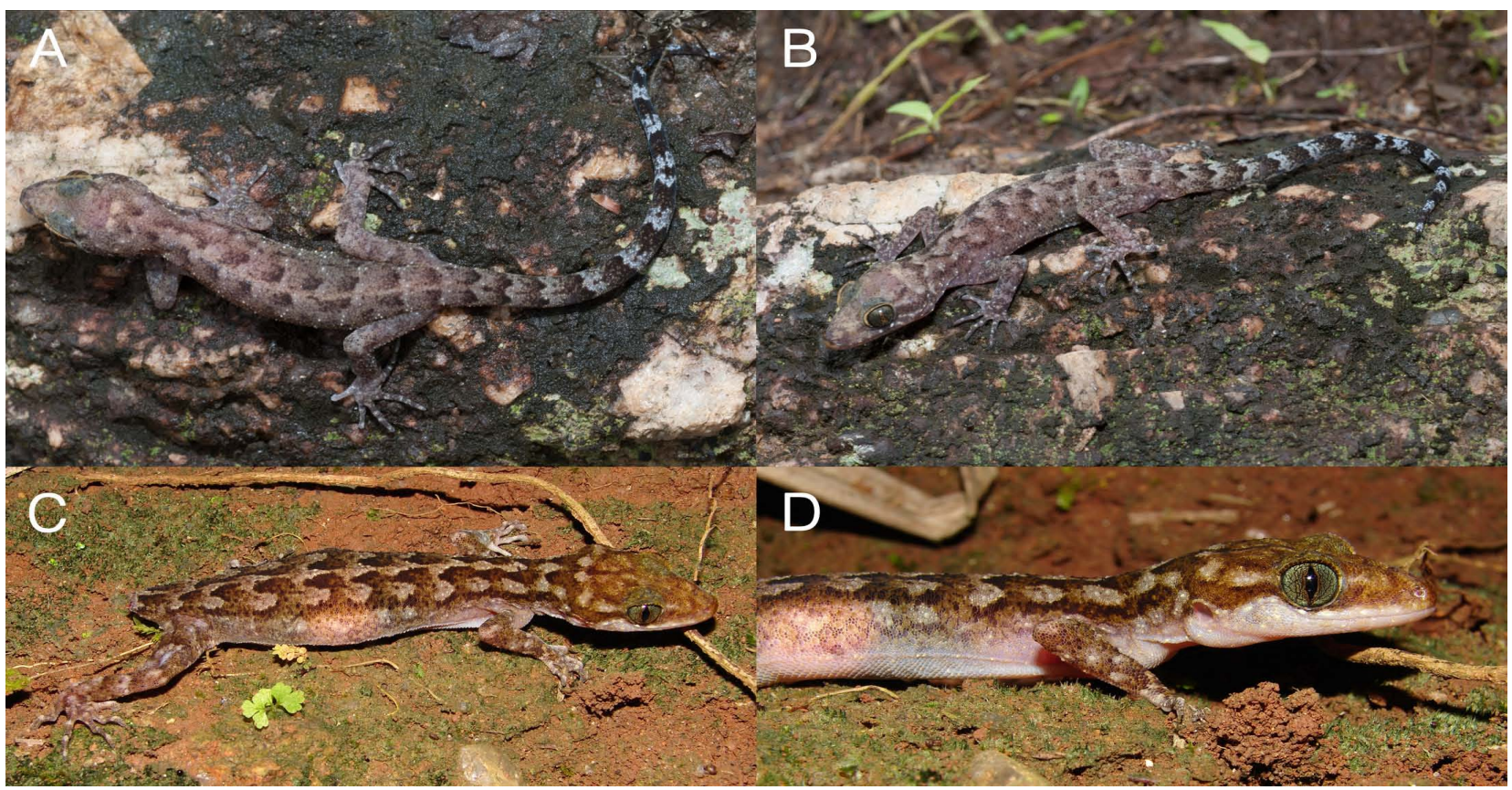

Figure 6. Cyrtodactylus urbanus in life: A-B. subadult male (BNHS 2852) from Saiden, Ri Bhoi District, Meghalaya State, north-east India; C-D. gravid adult female (not collected) from the type locality near Basistha Temple, Guwahati Metropolitan District, Assam State, north-east India. Images A-B taken ex-situ, C-D taken in-situ. 
(table 4), a hyphen is given to represent PcP number for the three paratypes, without an explanation of what the hyphen represents (e.g., it may mean " 0 ", or "data not assessed"). In the absence of a PcP series in females of some Cyrtodactylus species, often a series of pitted scales is present in its place. This information is important to describe since it can be very useful for comparing females of Cyrtodactylus species that are otherwise morphologically very similar. Unpublished images provided to us (Purkayastha pers. comm., 2020) of the cloacal region of the three female paratypes of $C$. urbanus clearly show that pitted scales are present (at least 11 on two individuals), but it cannot be determined with certainty whether additional peripheral scales possess pits/depressions, or whether any of the medial scales of the series with clearly deeper pits are fully perforated, representing true pores. We recommend that these specimens be re-examined to confirm the number of pits/pores; 22) nine transverse pairs of dark brown blotches on the dorsum counted from the nape to the sacrum on the Saiden specimen (BNHS 2852), 9-10 on the uncollected individual from Basistha (Fig. 6C, D) (vs. not described in Purkayastha et al., 2020a). The number of dark blotches on the dorsum has been used in comparisons between species of Cyrtodactylus and can be a useful character. Purkayastha et al. (2020a) described the dorsal coloration as follows "Dorsal pattern of 6-7 longitudinal rows of two indistinct transverse pale buff blotches outlined by light edges" in the species' "Diagnosis" section, which based on their figures (figs. 5 $\& 8)$ the authors appear to be describing transverse pale patches between the dark brown blotches, though it is also not clear whether these counts were made on the trunk only, or from the nape to the sacrum. Purkayastha et al. (2020a: table 5) compared "Transverse series of blotches on the dorsum" between related species, stating "6-8" for C. urbanus but again it is not clear whether they were describing the dark brown blotches, or aforementioned "pale buff blotches", or how the counts were made. Based on Purkayastha et al. (2020a: figs. 5 \& 8; 2020c: fig. 1) we determine that within the type series and their Nongpoh referred specimen, 8-10 transverse rows of paired dark brown blotches counted from the nape to the sacrum are present $(\mathrm{N}=8) ; 23)$ Tail segments indistinct, the second tail segment has eight scale rows dorsally, reduced to five rows ventrally (vs. not mentioned in Purkayastha et al., 2020a)

The previous section has highlighted a considerable number of errors, inconsistencies and ambiguities in the description of morphological characters between the "Diagnosis and comparison with regional congeners" section, the holotype description, and meristic counts given in tables in Purkayastha et al. (2020a). These issues urgently require clarification by the original authors of Purkayastha et al. (2020a) in the form of a published erratum to enable the correct diagnosis of further new species awaiting description in north-east India, and to prevent the potential misidentification of additional populations of $C$. urbanus for which molecular data are not available.

\section{DISCUSSION}

With regards to herpetofaunal diversity, Meghalaya State is historically the most well surveyed of the hilly states in north-east India. The past two decades has seen a growing number of new species of reptiles and amphibians being described from the state (e.g., Das et al., 2010; Mahony et al., 2011, 2013, 2018, 2020; Purkayastha \& Matsui, 2012; Datta-Roy et al., 2013; Kamei et al., 2013; Agarwal et al., 2018c) and the taxonomic status of other poorly known species being revised based on newly collected material (e.g., Mahony, 2008; Biju et al., 2016; Kamei \& Biju, 2016; Agarwal et al., 2018b; Mahony et al., 2018, 2020; Giri et al., 2019a, 2019b). The Garo Hills, however, are still relatively poorly surveyed. Few studies highlighting the region's herpetofaunal diversity have been published (e.g., Pillai \& Chanda, 1981; Mathew, 2010; Sen \& Mathew, 2010; Mathew \& Meetei, 2013; Sen et al., 2013; Sangma \& Saikia, 2014a, 2014b, 2015); however, several of these papers must be dealt with critically as they report several species misidentifications-e.g., Sangma and Saikia (2014a) reported Hemidactylus flaviviridis Rüppell, 1835, for the first time from Meghalaya giving figures (Sangma \& Saikia, 2014a: fig. 4) of a specimen clearly identifiable as $H$. cf. platyurus (Schneider, 1792), and H. "garnooti" (sic.- $H$. garnotii Duméril \& Bibron, 1836) for the first time from the Garo Hills giving a figure (Sangma \& Saikia, 2014a: fig. 5) of specimens clearly identifiable as $H$. frenatus Duméril and Bibron, 1836; Sangma and Saikia (2014b) reported Oligodon nikhili Whitaker and Dattatri, 1982 (otherwise known only from the type locality in south India) and $O$. kheriensis Acharji and Ray, 1936, based on photographed specimens without giving diagnostic characters that allow an accurate identification of either species; figured specimens (Sangma \& Saikia, 2014b: fig. 1) appear superficially similar to $O$. cyclurus (Cantor, 1839) and $O$. cinereus (Günther, 1864) (respectively), both of which are known from neighbouring regions.

Until now, published reports of Cyrtodactylus species from the Garo Hills include the following: $C$. "khasiensis" ("VR/ERS/ZSI/71" — specimen not examined in this study) from Baghmara Reserve Forest, South Garo Hills District (Mathew, 2010); C. "khasiensis" (no reported specimen voucher) from Balphakram National Park, South Garo Hills District (Pawar \& Birand, 2001); C. "khasiensis" (one specimen presumably in NERC/ZSI, voucher number not given) from Songsak, Williamnagar, East Garo Hills District (Mathew, 1995). At the time of those reports, the large-scale hidden diversity within the north-east Indian Cyrtodactylus was not known (Agarwal et al., 2014) and all populations superficially similar to $C$. khasiensis were lumped under this catch-all name. We suggest that these specimens be re-examined and compared with Cyrtodactylus bapme sp. nov., since current molecular sampling suggests that $C$. khasiensis sensu stricto should be considered as a Khasi Hills endemic species (e.g., Agarwal et al., 2014, 2018b, 2018c). 


\section{ACKNOWLEDGEMENTS}

RGK thanks the Department of Forests and Environment, Government of Meghalaya for fieldwork and specimen collection permit (No: FWC/G/173/Pt-II/295 dated May 8, 2014). RGK thanks Mrs. and Mr. Sangma for hosting in their home during field research in May to August 2014; especially acknowledges Dimdailung Kamei for providing a jeep and driver for local travels. This research was supported by the following funding: Rufford Foundation Small Grant (15255-1) and Marie Skłodowska-Curie Fellowship (PIIF-GA-2013-625870) to RGK; SM is currently supported by an Irish Research Council-Marie Skłodowska-Curie CAROLINE Fellowship (CLNE/2017/482). For access to molecular lab facilities and lab support, RGK thanks Praveen Karanth (Indian Institute of Science, Bangalore, India) and his students Chinta Sidhartha, Kunal Arekar, Maitreya Sil. We thank Jayaditya Purkayastha for providing unpublished photographs and information relating to the type series of Cyrtodactylus urbanus which dramatically improved our discussion of morphological variation in the species. Thanks to Aaron Bauer, Todd Jackman and Perry Wood Jr. for clarifying details associated with the sequence JX440526.1. For granting access to collections and curatorial assistance, SM thanks Colin McCarthy (NHMUK), G. Ramakrishna and B.H.C.K. Murthy (ZSIK); and for accessioning specimens RGK thanks Rahul Khot (BNHS). We thank Aaron Bauer and an anonymous reviewer for valuable comments and suggestions that have improved the manuscript.

\section{REFERENCES}

Acharji, M.N. \& Ray, H.C. (1936). A new species of Oligodon from the United Provinces (India). Records of the Indian Museum 38, 519-520.

Agarwal, I., Bauer, A.M., Jackman, T.R. \& Karanth, K.P. (2014). Insights into Himalayan biogeography from geckos: A molecular phylogeny of Cyrtodactylus (Squamata: Gekkonidae). Molecular Phylogenetics and Evolution 80, 145-155. DOI: 10.1016/j.ympev.2014.07.018

Agarwal, I., Khandekar, A. \& Bauer, A.M. (2018a). A new benttoed gecko (Squamata: Gekkonidae) from the Western Himalayas, Himachal Pradesh, India. Zootaxa 4446(4), 442454. DOI: $10.11646 /$ zootaxa.4446.4.2

Agarwal, I., Mahony, S., Giri, V.B., Chaitanya, R. \& Bauer, A.M. (2018b). Two new species of Cyrtodactylus Gray, 1827 (Squamata: Gekkonidae) with comments on name-bearing types from northeast India. Zootaxa 4420(3), 334-356. DOI: $10.11646 /$ zootaxa.4420.3.2

Agarwal, I., Mahony, S., Giri, V.B., Chaitanya, R. \& Bauer, A.M. (2018c). Six new Cyrtodactylus (Squamata: Gekkonidae) from northeast India. Zootaxa 4524(5), 501-535. DOI: 10.11646/zootaxa.4524.5.1

Ahsan, M.F. (1998). Herpetofauna of Bangladesh: present status, distribution and conservation. In: de Silva, A. (Ed.) Biology and Conservation of the Amphibians, Reptiles and their Habitats in South Asia, Proceedings of the International Conference on the Biology and Conservation of the South Asian Amphibians and Reptiles, 1-5 August 1996.
Peradeniya: Amphibia and Reptile Research Organization of Sri Lanka, pp. 9-17.

Al-Razi, H., Maria, M. \& Hasan, S. (2018). First record of the recently described Cyrtodactylus tripuraensis Agarwal, Mahony, Giri, Chaitanya \& Bauer, 2018 (Squamata, Gekkonidae) in Bangladesh. Check List 14 (6), 1105-1108.

Altschul, S.F., Gish, W., Miller, W., Myers, E.W. \& Lipman, D.J. (1990). Basic Local Alignment Search Tool. Journal of Molecular Biology 215, 403-410.

Annandale, N. (1906). A new gecko from the Eastern Himalayas. Journal of the Asiatic Society of Bengal 2(7), 287-288.

Annandale, N. (1913). The Indian geckos of the genus Gymnodactylus. Records of the Indian Museum 9, 309-326.

Bauer, A.M. (2002). Two new species of Cyrtodactylus (Squamata: Gekkonidae) from Myanmar. Proceedings of the California Academy of Science 53(7), 75-88.

Bauer, A.M. (2003). Descriptions of seven new Cyrtodactylus (Squamata: Gekkonidae) with a key to the species of Myanmar (Burma). Proceedings of the California Academy of Sciences 54, 463-498.

Bauer, A.M., Sumontha, M. \& Pauwels, O.S.G. (2003). Two new species of Cyrtodactylus (Reptilia: Squamata: Gekkonidae) from Thailand. Zootaxa 376, 1-18.

Bauer, A.M., Masroor, R., Titus-Mcquillan, J., Heinicke, M.P., Daza, J.D. \& Jackman, T.R. (2013). A preliminary phylogeny of the Palearctic naked-toed geckos (Reptilia: Squamata: Gekkonidae) with taxonomic implications. Zootaxa 3599(4), 301-324.

Benson, D.A., Cavanaugh, M., Clark, K., Karsch-Mizrachi, I., Lipman, D.J., Ostell, J. \& Sayers, E.W. (2017). GenBank. Nucleic Acids Research, 45(Database issue), D37-D42. DOI: 10.1093/nar/gkw1070

Biju, S.D., Senevirathne, G., Garg, S., Mahony, S., Kamei, R.G., Thomas, A., Shouche, Y., Raxworthy, C.J., Meegaskumbura, M. \& Van Bocxlaer, I. (2016). Frankixalus, a new rhacophorid genus of tree hole breeding frogs with oophagous tadpoles. PLOS ONE 11(1), e0145727. DOI:10.1371/journal. pone. 0145727

Blyth, E. (1861). Proceedings of the Society. Report of the Curator. Journal and Proceedings of the Asiatic Society of Bengal XXIX [1860], 87-115.

Boulenger, G.A. (1893). Concluding report on the reptiles and batrachians obtained in Burma by Signor L. Fea, dealing with the collection made in Pegu and the Karin Hills in 1887-8. Annali del Museo Civico di Storia Naturale di Genova, Series 2, 13, 304-347, pls. VII-XII.

Boulenger, G.A. (1905). On some batrachians and reptiles from Tibet. Annals and Magazine of Natural History Series 7, 15(88), 378-379.

Cantor, T.E. (1839). Spicilegium serpentium indicorum [part 1]. Proceedings of the Zoological Society of London 1839, 31-34.

Darevsky, I.S., Helfenberger, N., Orlov, N. \& Shah, K. (1998). Two new species of the genus Gonydactylus (Sauria: Gekkonidae) from eastern Nepal. Russian Journal of Herpetology $4(2$ "1997"), 89-93.

Das, A., Sharma, P., Surendran, H., Nath, A., Ghosh, S., Dutta, D., Mondol, J. \& Wangdi, Y. (2016). Additions to the herpetofauna of Royal Manas National Park, Bhutan, with six new country records. Herpetology Notes 9, 261-278.

Das, I., Tron, R.K.L., Rangad, D. \& Hooroo, R.N. (2010). A new species of Leptolalax (Anura: Megophryidae) from the 
sacred groves of Mawphlang, Meghalaya, north-eastern India. Zootaxa 2339 (1), 44-56.

Datta-Roy, A., Das, I., Bauer, A.M., Tron, R.K.L. \& Karanth, P. (2013). Lizard wears shades. a spectacled Sphenomorphus (Squamata:Scincidae), from the sacred forests of Mawphlang, Meghalaya, North-east India. Zootaxa 3701(2), 257-276.

Duda, P.L. \& Sahi, D.N. (1978). Cyrtodactylus himalayanus: a new gekkonid species from Jammu, India. Journal of Herpetology 12(3), 351-354.

Davis, H.R., Bauer, A.M., Jackman, T.R., Nashriq, I. \& Das, I. (2019). Uncovering karst endemism within Borneo: two new Cyrtodactylus species from Sarawak, Malaysia. Zootaxa 4614(2), 331-352. DOI: 10.11646/zootaxa.4614.2.4

Duméril, A.M.C. \& Bibron, G. (1836). Erpetologie Générale ou Histoire Naturelle Complete des Reptiles. Vol. 3. Paris: Libr. Encyclopédique Roret, i-iv + 528 pp. + [i].

Edgar, R.C. (2004). Muscle: a multiple sequence alignment method with reduced time and space complexity. $B M C$ Bioinformatics 5, 113. DOI: 10.1186/1471-2105-5-113

Gray, J.E. (1827). A synopsis of the genera of saurian reptiles, in which some new genera are indicated, and the others reviewed by actual examination. The Philosophical Magazine, or Annals of Chemistry, Mathematics, Astronomy, Natural History, and General Science 2, 54-58. DOI: 10.1080/14786442708675620

Giri, V.B., Chaitanya, R., Mahony, S., Lalrounga, S., Lalrinchhana, C., Das, A., Sarkar, V., Karanth, P. \& Deepak, V. (2019a). On the systematic status of the genus Oriocalotes Günther, 1864 (Squamata: Agamidae: Draconinae) with the description of a new species from Mizoram state, northeast India. Zootaxa 4638(4), 451-484. DOI: 10.11646/zootaxa.4638.4.1

Giri, V.B., Gower, D.J., Das, A., Lalremsanga, H.T., Lalronunga, S., Captain, A. \& Deepak, V. (2019b). A new genus and species of natricine snake from northeast India. Zootaxa 4603(2), 241-264.

Gopaldhara Tea Estate website, https:/gopaldharaindia.com/ finest-darjeeling-tea/ (accessed 24/06/2020).

Grismer, L.L., Wood Jr., P.L., Thura, M.K., Quah, E.S.H, Murdoch, M.L., Grismer, M.S., Herr, M.W., Lin, A. \& Kyaw, H. (2018a). Three more new species of Cyrtodactylus (Squamata: Gekkonidae) from the Salween Basin of eastern Myanmar under-score the urgent need for the conservation of karst habitats. Journal of Natural History 52 (19-20), 1243-1294. DOI: 10.1080/00222933.2018.1449911

Grismer, L.L., Wood Jr., P.L., Quah, E.S.H., Murdoch, M.L., Grismer, M.S., Herr, M.W. \& Lin, A. (2018b). A phylogenetic taxonomy of the Cyrtodactylus peguensis group (Reptilia: Squamata: Gekkonidae) with descriptions of two new species from Myanmar. PeerJ 6, e5575. DOI: 10.7717/peerj.5575

Grismer, L.L., Wood Jr., P.L., Thura, M.K., Win, N.M., Grismer, M.S., Trueblood, L.A. \& Quah, E.H.S. (2018c). A re-description of Cyrtodactylus chrysopylos Bauer (Squamata: Gekkonidae) with comments on the adaptive significance of orange coloration in hatchlings and descriptions of two new species from eastern Myanmar (Burma). Zootaxa 4527(2), 151-185.

Grismer, L.L., Wood Jr., P.L., Thura, M.K., Zin, T., Quah, E.S.H., Murdoch, M.L., Grismer, M.S., Lin, A., Kyaw, H. \& Lwin, N. (2018d). Twelve new species of Cyrtodactylus Gray (Squamata: Gekkonidae) from isolated limestone habitats in east-central and southern Myanmar demonstrate high localized diversity and unprecedented microendemism.
Zoological Journal of the Linnean Society 182(4), 862-959. DOI: $10.1093 /$ zoolinnean/z|x057

Grismer, L.L., Wood Jr., P.L., Thura, M.K., Win, N.M. \& Quah, E.S.H. (2019a). Two more new species of the Cyrtodactylus peguensis group (Squamata: Gekkonidae) from the fringes of the Ayeyarwady Basin, Myanmar. Zootaxa 4577(2), 274-294.

Grismer, L.L., Wood Jr., P.L., Quah, E.S.H., Thura, M.K., Herr, M.W. \& Lin, A.K. (2019b). A new species of forestdwelling Cyrtodactylus Gray (Squamata: Gekkonidae) from the Indawgyi Wildlife Sanctuary, Kachin State, Myanmar. Zootaxa 4623(1), 1-25.

Grismer, L.L., Wood Jr., P.L., Poyarkov, N.A., Le, M.D., Kraus, F., Agarwal, I., Oliver, P.M., Nguyen, S.N., Nguyen, T.Q., Karunarathna, S., Welton, L.J., Stuart, B.L., Luu, V.Q., Bauer, A.M., O'Connell, K.A., Quah, E.S.H., Chan, K.O., Ziegler, T., Ngo \& H. et al. (2021). Phylogenetic partitioning of the thirdlargest vertebrate genus in the world, Cyrtodactylus Gray, 1827 (Reptilia; Squamata; Gekkonidae) and its relevance to taxonomy and conservation. Vertebrate Zoology 71, 101-154.

Günther, A. (1864). The Reptiles of British India. Taylor \& Francis, London. xxvii + 452 pp., XXVI pls.

Jerdon, T.C. (1870). Notes on Indian herpetology. Proceedings of the Asiatic Society Bengal 1870, 66-85.

Johnson, C.B., Quah, E.S.H., Anuar, S., Muin, M.A., Wood Jr., P.L., Grismer, J.L., Greer, L.F., Chan, K.O., Ahmad, N., Bauer, A.M. \& Grismer, L.L. (2012). Phylogeography, geographic variation, and taxonomy of the Bent-toed Gecko Cyrtodactylus quadrivirgatus Taylor, 1962 from Peninsular Malaysia with the description of a new swamp dwelling species. Zootaxa 3406, 39-58.

Kamei, R.G. \& Biju, S.D. (2016). On the taxonomic status of Ichthyophis husaini Pillai \& Ravichandran, 1999 (Amphibia: Gymnophiona: Ichthyophiidae), Zootaxa 4079(1), 140-150.

Kamei, R.G., Gower, D.J., Wilkinson, M. \& Biju, S.D. (2013). Systematics of the caecilian family Chikilidae (Amphibia: Gymnophiona) with the description of three new species of Chikila from northeast India. Zootaxa 3666(4), 401-435.

Kearse, M., Moir, R., Wilson, A., Stones-Havas, S., Cheung, M., Sturrock, S., Buxton, S.,Cooper, A., Markowitz, S. \& Duran, C. et al. (2012). Geneious Basic: an integrated and extendable desktop software platform for the organization and analysis of sequence data. Bioinformatics 28(12), 1647-1649. DOI: 10.1093/bioinformatics/bts199

Khan, M.S. (1993). A new angular-toed gecko from Pakistan, with remarks on the taxonomy and a key to the species belonging to genus Cyrtodactylus (Reptilia: Sauria: Gekkonidae). Pakistan Journal of Zoology 25(1), 67-73.

Kumar, S., Stecher, G. \& Tamura, K. (2016). MEGA7: Molecular Evolutionary Genetics Analysis Version 7.0 for bigger datasets. Molecular Biology and Evolution 33(7), 18701874. DOI: $10.1093 / \mathrm{molbev} / \mathrm{msw} 054$

Li, P.-P. (2007). Description of a new subspecies of Cyrtodactylus khasiensis from China. Acta Zootaxonomica Sinica 32, 733737.

Macey, J.R., Larson, A., Ananjeva, N.B., Fang, Z. \& Papenfuss, T.J. (1997). Two novel gene orders and the role of lightstrand replication in rearrangement of the vertebrate mitochondrial genome. Molecular Biology and Evolution 14, 91-104. DOI: 10.1093/oxfordjournals.molbev.a025706

Macey, J.R., Schulte II, J.A., Larson, A., Ananjeva, N.B., Yuezhao, W., Pethiyagoda, R., Rastegar-Pouyani, N. \& Papenfuss, 
T.J. (2000). Evaluating trans-Tethys migration: an example using acrodont lizard phylogenetics. Systematic Biology 49, 233-256.

Mahony, S. (2008). Redescription and generic reallocation of Rana mawphlangensis Pillai \& Chanda, 1977 (Amphibia: Ranidae). Hamadryad 33, 1-12.

Mahony, S. (2009). Taxonomic status of Cyrtodactylus khasiensis tamaiensis (Smith, 1940) and description of a new species allied to Cyrtodactylus chrysopylos Bauer, 2003 from Myanmar (Reptilia: Gekkonidae). Hamadryad 34(1), 62-74.

Mahony, S. \& Reza A.H.M.A. (2008). A herpetofaunal collection from the Chittagong Hill tracts, Bangladesh, with two new species records for the country. Hamadryad 32(1), 45-56.

Mahony, S., Ahmed, M., Hossain, M.K., Kabir, M.M. \& Hasan, M.K. (2009a). Cyrtodactylus ayeyarwadyensis Bauer, 2003 (Reptilia: Gekkonidae) in Bangladesh with habitat details of new collection localities and a discussion of morphological variation. Salamandra 45(4), 245-250.

Mahony, S., Hasan, M.K., Kabir, M.M., Ahmed, M. \& Hossain, M.K. (2009b). A catalogue of herpetofauna in the collection of Jahangirnagar University, Dhaka, Bangladesh. Hamadryad 34(1), 80-94.

Mahony, S., Sengupta, S., Kamei, R.G. \& Biju, S.D. (2011). A new low altitude species of Megophrys Kuhl and van Hasselt (Amphibia: Megophryidae), from Assam, northeast India. Zootaxa 3059, 36-46.

Mahony, S., Teeling, E.C. \& Biju, S.D. (2013). Three new species of horned frogs, Megophrys (Amphibia: Megophryidae), from Northeast India, with a resolution to the identity of Megophrys boettgeri populations reported from the region. Zootaxa 3722(2), 143-169.

Mahony, S., Kamei, R.G., Teeling, E.C. \& Biju, S.D. (2018). Cryptic diversity within the Megophrys major species group (Amphibia: Megophryidae) of the Asian Horned Frogs: Phylogenetic perspectives and a taxonomic revision of South Asian taxa, with descriptions of four new species. Zootaxa 4523(1), 1-96. DOI: 10.11646/zootaxa.4523.1.1

Mahony, S., Kamei, R.G., Teeling, E.C. \& Biju, S.D. (2020). Taxonomic review of the Asian horned frogs (Amphibia: Megophrys Kuhl \& Van Hasselt) of northeast India and Bangladesh previously misidentified as $M$. parva (Boulenger), with descriptions of three new species. Journal of Natural History 54(1-4), 119-194. DOI: 10.1080/00222933.2020.1736679

Mathew, R. (1995). Reptilia. In: Ghosh, A. K. (Ed.) State Fauna Series 4: Fauna of Meghalaya. Part 1., Calcutta: Zoological Survey of India, pp. 379-454.

Mathew, R. (2010). Reptilia. In: Director (Ed.) Faunal Diversity of Baghmara Reserve Forest, Conservation Area Series, 44, Calcutta: Zoological Survey of India, pp. 77-81.

Mathew, R. \& Meetei, A.B. (2013). Reptilia. In: Director (Ed.) Fauna of Nokrek Biosphere Reserve, Conservation Area Series, 45, Calcutta: Zoological Survey of India, pp. 117-124.

Miller, M.A., Pfeiffer, W. \& Schwartz, T. (2010). Creating the CIPRES science gateway for inference of large phylogenetic trees. In: Institute of Electrical and Electronics Engineers (Ed.) Proceedings of the Gateway Computing Environments Workshop (GCE). New Orleans: Piscataway, pp. 1-8. DOI: 10.1109/GCE.2010.5676129

Mirza, Z.A., Bhosale, H., Ansari, F., Phansalkar, P., Sawant, M., Gowande, G. \& Patel, H. (2021). A new species of geckos of the genus Cyrtodactylus Gray, 1827 from Arunachal Pradesh, India. Evolutionary Systematics 5, 13-23.

Muansanga, L., Decemson, H., Biakzuala, L., Hmar, G.Z., Lalremsanga, H.T., Das, M. \& Purkayastha, J. (2020). First record of the Jampui bent-toed gecko, Cyrtodactylus montanus Agarwal, Mahony, Giri, Chaitanya, and Bauer 2018 (Squamata: Gekkonidae), from Mizoram, India. ICRF Reptiles \& Amphibians Conservation and Natural History 27(2), 267-268.

Nandy, S. \& Das, A.K. (2013). Comparing tree diversity and population structure between a traditional agroforestry system and natural forests of Barak valley, Northeast India. International Journal of Biodiversity Science, Ecosystem Services \& Management 9(2), 104-113.

Pawar, S. \& Birand, A. (2001). A Survey of Amphibians, Reptiles, and Birds of Northeast India. CERC Technical Report \#6. Mysore: Center for Ecological Research and Conservation, $75 \mathrm{pp}$.

Phaomei, G. \& Mathew, B. (2019). Morphological characterization of jackfruit (Artocarpus heterophyllus Lam.) in West Garo hills district of Meghalaya. Plant Archives 19(2), 2081-2087.

Pillai, R.S. \& Chanda, S.K. (1981). Amphibian fauna of Garo Hills, Meghalaya with description of a new species of Rana. Records of the Zoological Survey of India 79, 159-168.

Purkayastha, J. \& Matsui, M. (2012). A new species of Fejervarya (Anura: Dicroglossidae) from Mawphlang, northeastern India. Asian Herpetological Research 3(1), 31-37.

Purkayastha, J., Das, M., Bohra, S.C., Bauer, A.M. \& Agarwal, I. (2020a). Another new Cyrtodactylus (Squamata: Gekkonidae) from Guwahati, Assam, India. Zootaxa 4732(3), 375-392. DOI: 10.11646/zootaxa.4732.3.2

Purkayastha, J., Roychoudhury, S., Biswas, B.B., Das, M. \& Sengupta, S. (2020b). Herpetofaunal diversity and conservation status in Amchang Wildlife Sanctuary of Assam, India. In: Roy, N., Roychoudhury, S., Nautiyal, S., Agarwal, S. \& Baksi, S. (Eds.) Socio-economic and Ecobiological Dimensions in Resource use and Conservation. Strategies for Sustainability. Cham: Springer, pp. 217-223.

Purkayastha, J., Bohra, S.C. \& Das, M. (2020c). First record of the Urban Bent-toed Gecko, Cyrtodactylus urbanus Purkayastha, Das, Bohra, Bauer, and Agarwal 2018 (Squamata: Gekkonidae), from Meghalaya, India. ICRF Reptiles \& Amphibians Conservation and Natural History 27(3), 512-513.

Rahman, M., Rahman, M.M. \& Islam, M. (2009). Financial viability and conservation role of betel leaf based agroforestry: an indigenous hill farming system of Khasia community in Bangladesh. Journal of Forestry Research 20(2), 131-136.

Rambaut, A. (2009). FigTree version 1.3.1. Computer program distributed by the author. http://tree.bio.ed.ac.uk/ software/figtree/

Riyanto, A., Arida, E. \& Koch, A. (2018). Cyrtodactylus tahuna sp. nov., a new bent-toed gecko (Reptilia: Squamata: Gekkonidae) from Sangihe Island, North Sulawesi, Indonesia. Zootaxa 4399(2), 220-232. DOI: 10.11646/ zootaxa.4399.2.6

Rüppell, E. (1835). Neue Wirbelthiere zu der Fauna von Abyssinien gehörig, entdeckt und beschrieben. Amphibien. Frankfurt am Main: S. Schmerber, [2] + 18 pp., 6 pl.

Sangma, M.A. \& Saikia, P.K. (2014a). New records of lizards in 
Tura peak of West Garo Hills, Meghalaya, India. Journal on New Biological Reports 3(3), 175-181.

Sangma, M.A. \& Saikia, P.K. (2014b). New records of snakes in Tura peak of West Garo Hills, Meghalaya, India. Journal on New Biological Reports 3(3), 262-270.

Sangma, M.A. \& Saikia, P.K. (2015). Checklist of amphibians inventoried from Tura Peak of West Garo Hills, Meghalaya, India. Journal of Global Bioscience 4(5), 2404-2424.

Schlegel, H. (1837). Abbildungen neuer oder unvollständig bekannter Amphibien, nach der Natur oder dem Leben entworfen. Düsseldorf: Arnz \& Comp., i-xiv + 141 pp. [+ pl. 1-50: 1837-1844].

Schneider, I.G. (1792). Amphibiorum physiologiae specimen alterum historiam et species generis Stellionum seu Geckonum sistens. Apitzil: Traiectiad Viadrum, $54 \mathrm{pp}$.

Sen, N. \& Mathew, R. (2010). Amphibia. In: Director (Ed.) Faunal Diversity of Baghmara Reserve Forest, Conservation Area Series, 44, Calcutta: Zoological Survey of India, pp. 69-76.

Sen, N., Mathew, R. \& Meetei, A.B. (2013). Amphibia. In: Director (Ed.) Fauna of Nokrek Biosphere Reserve, Conservation Area Series, 45, Calcutta: Zoological Survey of India, pp. 105-115.

Siler, C.D., Oaks, J.R., Esselstyn, J.A., Diesmos, A.C. \& Brown, R.M. (2010). Phylogeny and biogeography of Philippine bent-toed geckos (Gekkonidae: Cyrtodactylus) contradict a prevailing model of Pleistocene diversification. Molecular Phylogenetics and Evolution 55, 699-710.

Smith, M.A. (1935). The Fauna of British India, including Ceylon and Burma. Reptiles and Amphibia. Vol. II. Sauria. London: Taylor and Francis, xiii + 440 pp., pls. $1+2$ maps.

Smith, M.A. (1940). The amphibians and reptiles obtained by Mr. Ronald Kaulback in Upper Burma. Records of the Indian Museum 42, 465-486.

Stamatakis, A. (2014). RAxML version 8: a tool for phylogenetic analysis and post-analysis of large phylogenies. Bioinformatics 30, 1312-1313. DOI: 10.1093/ bioinformatics/btu033

Steindachner, F. (1867). Reptilien. In: Reise der Österreichischen Fregatte Novara um die Erde in den Jahren 1857, 1858, 1859 unter den Befehlen des Commodore B. von WüllerstorfUrbair (Zoologie), Vol. 1, part 3. Wien: K. Gerold's Sohn/ Kaiserlich-Königl. Hof- und Staatsdruckerei, pp. 1-98, 3 pls.

Stoliczka, F. (1871). Notes on new or little-known Indian lizards. Proceedings of the Asiatic Society of Bengal 1871 (Sept.), 192-195.
Tamura, K. \& Nei, M. (1993). Estimation of the number of nucleotide substitutions in the control region of mitochondrial DNA in humans and chimpanzees. Molecular Biology and Evolution 10(3), 512-526. DOI: 10.1093/ oxfordjournals.molbev.a040023

Wang, K., Ren, J., Chen, H., Lyu, Z., Guo, X., Jiang, K., Chen, J., Li, J., Guo, P., Wang, Y. \& Che, J. (2020). The updated checklists of amphibians and reptiles of China. Biodiversity Science 28(2), 189-218.

Whitaker, R. \& Dattatri, S. (1982). A new species of Oligodon from the Palni Hills, south India (Serpentes: Colubridae). Journal of the Bombay Natural History Society 79(3), 630-631.

Wood Jr., P.L., Heinicke, M.P., Jackman, T.R. \& Bauer, A.M. (2012). Phylogeny of bent-toed geckos (Cyrtodactylus) reveals a west to east pattern of diversification. Molecular Phylogenetics and Evolution 65(3), 992-1003. DOI: 10.1016/j.ympev.2012.08.025

\section{APPENDIX I}

\section{Comparative specimens examined.}

Cyrtodactylus himalayicus: holotype: male (ZSIK 15716), from "Kurseong, Darjeeling Dist. (5,000 ft)" [=Kurseong Subdivision (ca. $1524 \mathrm{~m}$ asl.), Darjeeling District, West Bengal State, India]; referred material: adult female (ZSIK 19546), from “Gopaldhara, Darjeling Dist." [=Gopaldhara Tea Estate, near Mirik Town, Darjeeling District, West Bengal State, India].

Cyrtodactylus khasiensis: lectotype: adult female (BMNH 1906.8.10.4) from Khasi Hills, Meghalaya, India; paralectotypes: adult female (ZSIK 6199), adult male (ZSIK 6197), collected along with lectotype; referred material: adult males (ZSIK 5831, ZSIK 5832), adult female (ZSIK 5828), from "Cherrapunjee" [now Sohra Town, East Khasi Hills District, Meghalaya State, India].

Cyrtodactylus mandalayensis: holotype: subadult male (BMNH 1900.9.20.1), from Mogok, Pyin Oo Lwin District, Mandalay Region, Myanmar.

Cyrtodactylus tamaiensis: holotype: adult male (BMNH 1946.823.22), from "Pangnamdim, Nam Tamai Valley, Burma" [Pangnamdim, Kachin State, Myanmar].

Accepted: 8 April 2021 